Rhode Island College

Digital Commons @ RIC

Master's Theses, Dissertations, Graduate Research and Major Papers Overview

$11-14-2019$

\title{
Ambassador Between Two Nations: Shakespeare in American Ideology
}

Nicholas Jaroma

Follow this and additional works at: https://digitalcommons.ric.edu/etd

Part of the Literature in English, British Isles Commons, and the Literature in English, North America Commons

\section{Recommended Citation}

Jaroma, Nicholas, "Ambassador Between Two Nations: Shakespeare in American Ideology" (2019).

Master's Theses, Dissertations, Graduate Research and Major Papers Overview. 309.

https://digitalcommons.ric.edu/etd/309

This Thesis is brought to you for free and open access by Digital Commons @ RIC. It has been accepted for inclusion in Master's Theses, Dissertations, Graduate Research and Major Papers Overview by an authorized administrator of Digital Commons @ RIC. For more information, please contact digitalcommons@ric.edu. 
AMBASSADOR BETWEEN TWO NATIONS

\title{
SHAKESPEARE IN AMERICAN IDEOLOGY
}

\author{
By Nicholas Jaroma
}

\begin{abstract}
A Thesis Submitted in Partial Fulfillment
of the Requirements for the Master of English in

The Department of English
\end{abstract}

The School of Arts and Sciences

Rhode Island College

2019 


\begin{abstract}
$\underline{\text { Abstract }}$
The purpose of this thesis was to examine William Shakespeare's role in American ideology. Utilizing the theoretical approaches of Louis Althusser, Michel Foucault, adaptation and appropriation theories, and Critical Race Theory, I argue that Shakespeare is an integral part of American history and culture by how his works factor into American ideologies, particularly within ideologies focusing on race and colonialism. Specific plays and Shakespeare's texts are analyzed, and I also follow the literary history of Americans in response to these plays. My first chapter looks at the Revolutionary and early republic eras, with particular focus on John Adams, his son John Quincy Adams, and their analyses of Shakespeare's works. The second chapter highlighted the Civil War era, and the Confederate sympathizer Mary Preston's analyses of some of Shakespeare's plays. The third chapter looked at how Shakespeare's plays, particularly Julius Caesar, may have factored into President Abraham Lincoln's assassination. My final chapter analyzed the early twentieth century, and how Shakespeare was used to push both racist and progressive ideologies. The conclusion looks at how Shakespeare and the Humanities are relevant in America in the twenty-first century. The conclusion of the thesis is that authoritative power, whether that be in government, or in the perception of the Author, must always be challenged if society is to progress.
\end{abstract}




\section{Table of Contents}

Introduction: Friends, Romans, Countrymen, Lend Me Your Ears.......................

Chapter I: To You I am Bound for Life and Education - Shakespeare and Shedding the Bonds of England....................................................... 14

Chapter II: Now is the Winter of Our Discontent - Shakespeare, North and South......30

Chapter III: The Noblest Roman of Them All - Booth, Lincoln, Shakespeare..........49

Chapter IV: Brave New World That Has Such People In't - Shakespeare in the Dawn of the Twentieth Century.......................................................... 61

Conclusion: The Fault, Dear Brutus, Is Not in Our Stars, But In Ourselves............81

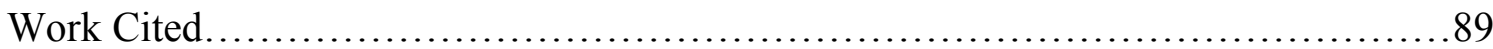


Jaroma 1

\section{$\underline{\text { Introduction }}$}

Friends, Romans, Countrymen, Lend Me Your Ears

In Act III, scene 2 of William Shakespeare's play Julius Caesar, the characters of Brutus and Antony both speak to the crowd of subjects with the same purpose in mind: win the crowd over to their side. Julius Caesar, Rome's leader, has just been assassinated by Brutus and his fellow conspirators in the previous scene, and Brutus wants the crowd to back their cause rather than avenge Caesar's assassination. Antony, pretending to be on Brutus' side, secretly wants to avenge Caesar's assassination, and plans to convince the crowd to join his side (Julius Caesar 3.1.256-277). It is agreed that Brutus would speak first to the people, followed by Antony who Brutus and the other conspirators believe will back them up (JC 3.1.236-244). However, both are able to plead their case before the Roman people, but both do it in very different styles.

Brutus uses his language to relate to the people, while Antony uses his language to appeal to their emotions. When Brutus speaks to the crowd, he speaks in prose $(J C$ 3.2.12-31). While Shakespeare would vary how he used prose and verse throughout his career, both were typically used to show class: verse for people of nobility, prose for commoners (Crystal 208). While Brutus is a senator, a member of Rome's upper class, he chooses to speak in prose to the subjects. Prose is the language of ordinary speech (Crystal 107), and Brutus chooses to speak in the language of the common Roman citizens to show that he relates to the people in order to convince them to support his cause. After Brutus leaves, Antony speaks to the crowd in verse (JC 3.2.71-105). While 
this is the language of the upper class, it is also the language of poetry (Crystal 107-108), language intended to elicit feelings and emotions, such as anger over the death of a leader. While Antony was successful and Brutus failed, both used their language in specific ways for personal gain. How one chooses to use their language to support an agenda is common within ideological practices. Sometimes it is not the speaker's own words used in this strategy. Sometimes the works of an authoritative figure are appropriated to support a cause, an authoritative figure such as Shakespeare.

Shakespeare's works have been celebrated and analyzed for centuries. He is England's national poet. However, his legacy casts a huge shadow across the pond in America. Shakespeare has had a significant presence in America since before it was a country. Shakespeare in America: An Anthology from the Revolution to Now and Americans on Shakespeare: 1776-1914, collected and edited by James Shapiro and Peter Rawlings respectively, include dozens of documents by Americans celebrating and analyzing Shakespeare and his works, often relating him to American concerns and situations. His influence and respect within America is so immense that it is as if Shakespeare is an American author.

The entries in these anthologies were written by Americans from various backgrounds including writers like Edgar Allan Poe, journalists such as Frederick Wadsworth Loring, and politicians such as Henry Cabot Lodge. Even presidents wrote about Shakespeare. Bill Clinton wrote the forward to Shakespeare in America. He wrote about his interpretations of the play Macbeth, "That was an important early lesson about the perils of blind ambition, and the emptiness of power disconnected from higher 
purpose. I always cherished that early lesson — and tried never to forget it. Macbeth is a great play about someone whose immense ambition had an ethically inadequate object" (Clinton xviii). Three other former presidents have entries in both collections, all from different parties and ideological views. Many Americans would use Shakespeare to justify or support an ideological position. Similarly to Brutus and Antony in their speeches, Americans interpreted and wrote about Shakespeare through specific ideological lenses in order to further their own agendas. Specific ideological lenses such as the nature of war, how to structure a government, and particularly white supremacy were included in how Americans viewed and interpreted Shakespeare.

Louis Althusser wrote a lot about ideology in his essay "Ideology and Ideological State Apparatuses: Notes towards an Investigation.” Althusser has much to write about the State. Within the State, the ruling class subjects the working class in order to serve the ruling class' ends. For Marxists, the State is also referred to as "the State apparatus" (Althusser 92). ${ }^{1}$ The State apparatus is when the working class in a society is forced to submit by "the police, the courts, the prisons; but also the army, which ... intervenes directly as a supplementary repressive force in the last instance, when the police and its specialized auxiliary corps are 'outrun by events'; and above this ensemble, the head of State, the government and the administration" (Althusser 92). Althusser refers to this as the "Repressive State Apparatus." However, he also adds another State apparatus, the titular "Ideological State Apparatuses," or "ISAs.” The most important distinction

\footnotetext{
${ }^{1}$ Italics are Althusser's. Punctuation and spelling for all documents is kept in the author's original unless otherwise noted.
} 
between the two is how they function: "The Repressive State Apparatus functions 'by violence', whereas the Ideological State Apparatuses function 'by ideology"' (Althusser 97). Althusser clarifies that while both the RSA and ISAs function with both violence and ideology, the RSA functions predominately through violence, while ISAs function predominately through ideology. Althusser further explains how ISAs work, that the working class submits to and is manipulated by the ruling ideology by the ruling class through words. This is often achieved through institutions such as schools, churches, and the military (Althusser 89). For my thesis, I am concerned with ISAs, since I am interested in how Americans interpreted and wrote about Shakespeare and his works to support various ideological agendas, such as white supremacy, which they (not necessarily the State or government in all cases, sometimes even ordinary citizens) pushed on the public.

On ideology, Althusser presents two theses: I) "Ideology represents the imaginary relationship of individuals to their real conditions of existence” (Althusser 109), and II) despite this, "Ideology has a material existence" (Althusser 112). What that means is ideology is imaginary, but it also governs our actions. Althusser provides the example of a theist. That person's belief in a god is their ideology and is (in Althusser's opinion) imaginary. However, "if he believes in God, he goes to Church to attend Mass, kneels, prays, confesses, does penance ... and naturally repents and so on” (Althusser 113). These actions are the material existence of this person's ideology. Everyone has an ideological position whether they admit it or not. It governs and directs our lives and directs our actions, so of course the State would like to manage it so that they may 
manage the lives of the populace. That is why I am interested in studying ideology. While there are many different theoretical approaches one can use to analyze Shakespeare's role in American culture, ideology is the one I am focused on because I argue that it is one of the most important topics since it has such a significant impact on people's lives. Racist ideologies in particular have certainly dominated American culture and government policies throughout American history, effecting the ways both the oppressors and the oppressed lived their lives.

Michel Foucault wrote about similar ideas to Althusser's in his essay “The Discourse on Language." For Foucault, "discourse is really only an activity, of writing in the first case, of reading in the second and exchange in the third" (Foucault, "The Discourse on Language" 228). For example, Shakespeare writes a play, others see or read it, and then others exchange ideas or critiques on the play. Foucault writes that whatever power discourse has comes from those who participate in it (Foucault, "The Discourse on Language" 216). However, Foucault also mentions that discourse is "considered precious and desirable" when it is "linked to the exercise of power" (Foucault, "The Discourse on Language" 218). While Althusser's ISAs were used to promote the ruling ideology, Foucault's discourse is used to promote a "truth" that a society holds dear (Foucault, "The Discourse on Language" 219), that truth being "wealth, fertility and sweet strength in all its insidious universality" (Foucault, "The Discourse on Language" 220). There are clearly social expectations of what is appropriate for discussion, as well as when one can discuss such subjects with the strictest prohibitions surrounding sexuality and politics (Foucault, "The Discourse on Language" 216). Forms of discourse that Foucault 
mentions are ones that are dictated through culture, "I suppose, though I am not altogether sure, there is barely a society without its major narratives, told, retold and varied; formulae, texts, ritualised texts to be spoken in well-defined circumstances; things said once, and conserved because people suspect some hidden secret or wealth lies buried within" (Foucault, "The Discourse on Language" 220). That is clearly applicable to Shakespeare, who is already one of the most popular authors in the world.

While there are many ideological agendas Americans have promoted, the most common ideologies in America are related to race and colonialism. While critical race theorists have many varied views and ideas, one point that all of them agree upon is "that racism is ordinary, not aberrational-'normal science,' the usual way society does business, the common, everyday experience of most people of color" (Delgado and Stefancic 7). Also, race may be the most significant ideology in the United States, as in this country race often comes into play in "discourses on class, sexual license, repressions, formations, and exercises of power" (Klages 121). Racism has certainly been a problem since the founding of this country. The work of María Lugones used Althusser's theory of ISAs and applied it to race theory, developing a list of eight "racial ISAs" (Klages 119). There are two that will be of particular focus in this thesis. The first is that "racial classification is given meaning by particular organizations of social, political, economic ... interaction. In other words, the dominant culture sets the rules, via RSAs and ISAs, for how members of nondominant cultures can act or what social roles they can fill" (Klages 120). Racist ideologies come from those who are in a position of power, "the dominant culture," to promote these racial ISAs on how the Other 
supposedly is. After all, race is a social construct (Delgado and Stefancic 7). The second point, "The racial state creates ideologies that justify the systems of racial classification and the structures and organizations based on such classifications" (Klages 120). The dominant culture has to create more ideologies to justify these horrible views and acts. These two points are closely related and very applicable to how Americans, from a president to a common citizen, would use Shakespeare to push racist ideologies. This thesis will explore how Americans used Shakespeare to characterize and govern the Other.

Foucault mentions that "a single work of literature can give rise simultaneously, to several distinct types of discourse" (Foucault, “The Discourse on Language” 221). Shakespeare's works have done just that for centuries. Julie Sanders in her book Adaptation and Appropriation writes "that these processes [adaptation and appropriations] are frequently, if not inevitably, political acts” (123). Sanders also mentions that "the adaptation of Shakespeare invariably makes him 'fit' for new cultural contexts and political ideologies different from his own age” (58). Shakespeare can be used to support various ideological ends by others. In her book $A$ Theory of Adaptation, Linda Hutcheon mentions that one of the reasons for adapting is politically motivated. The adapter "not only interprets the work but in so doing they also take a position on it" (Hutcheon 92). Shakespeare is also adapted and appropriated often through an ideological lens, as "many Shakespearean appropriations are motivated by a political commitment" (Sanders 71). But why choose Shakespeare? Why is he the most popular author in the world? What makes him so special? 
In his essay, "What Is an Author?" Foucault examines what he calls "the author function." Foucault states that while the function of the author is no longer apparent in scientific fields, it still thrives in literary analysis ("What Is an Author?" 222-23). One area where Foucault focuses is on the author's name. For example, when someone mentions "Dickens," while they may be referring to the author Charles Dickens as a person, they could also be referring to his works, his themes, or things that are similar to his works or themes - or perhaps his authority as an author (Foucault, "What Is an Author?" 220-21). In that sense, the author represents a multitude of ideas, works, and people. Foucault also writes about the connection between authors and ideology, "When a historically given function is represented in a figure that inserts it, one has an ideological production" ("What Is an Author?" 228). Shakespeare being a literary figure in America also adds a racial emphasis to his works. According to Literary Theory: The Complete Guide, the work of Toni Morrison argues that "literature produced in a historically racialized society like the United States always engages with the racial dynamics of whiteness and blackness" (Klages 121), even if the text itself supposedly has little or nothing to do with race. While Foucault also mentions that doing an ideological type of analysis can limit interpretations of the author and their works ("What Is an Author?" 228), it is those types of interpretations in which I am interested in how Shakespeare functions as an author.

Imagine the power behind the name of Shakespeare. He is arguably the most canonical figure in literature, and there are thousands of books written on him and his works. Of course, no one author has had quite the effect that Shakespeare has had. This is 
true in America, England, and beyond. A reason why Shakespeare is so highly regarded is because his works have spread globally. It also does not hurt that his works are in the public domain. Another boon is that Shakespeare is one of the major authors studied by students and scholars (Sanders 60). Shakespeare courses are very popular within college English departments. At Rhode Island College, English undergraduate education majors are required to take a Shakespeare course on him, and courses fill every semester. One of the purposes of adapting and appropriating Shakespeare is to gain respect in cultural capital by adapting such praised works (Hutcheon 92). If one knows Shakespeare well, then that shows others that this person is an intellectual, well-versed in cultural topics. That is another reason why Shakespeare is often adapted throughout the world. He is arguably the most celebrated author!

In his chapter on Shakespeare in his book The Western Canon: The Books and School of the Ages, Harold Bloom refers to Shakespeare as the "Center of the Canon," (43). "Canon" is a very appropriate word to use with regards to Shakespeare's works. Shakespeare's only rival, the only thing that surpasses him in terms of influence and literary respect, in Western culture at the very least, is the Bible. Chapter five of Thomas C. Foster's book How to Read Literature Like a Professor: A Lively and Entertaining Guide to Reading Between the Lines is titled "When in Doubt, It's from Shakespeare ..." Chapter six's title completes the sentence “... Or the Bible.” This is something reflected in American culture specifically as Americans would often have both books during westward expansion (Marx 1). Several of the documents in both collections equate Shakespeare's works with the Bible, such as the lecture "Shakespeare and American 
Culture” by Joseph Quincy Adams, who comments, “'Shakespeare and the Bible'-so the common phrase ran, linking the two in superlative evaluation; and no man was regarded complete who failed to know both" (430). Some even refer to Shakespeare as a god such as Charles Sprague in his poem "Prize Ode," where he refers to Shakespeare as "God of the glorious Lyre" (36)!

What does that say about Shakespeare when the only true rival was and is believed to be the word of God? It means Shakespeare's reputation is beyond reproach generally speaking, and this could also be potentially dangerous as the author can be used to represent any number of ideas and values. Notice that I specified that the Bible and Shakespeare were the most influential in Western culture. These texts would be used to promote "Western values" onto colonized peoples. Western books themselves were often tools of colonization. Similar to some of the other technologies the colonizers brought with them, an unfamiliar book like the Bible or the works of Shakespeare could be viewed by the colonized as "mystical, magical, and thus a symbol of the greater wisdom and power of the colonizing culture," particularly if the colonized culture was one that passed down stories and information orally (Klages 138). Shakespeare's status as an author in Western countries was used to suppress other cultures. For this reason, my thesis seeks to challenge the name of Shakespeare.

It is no wonder why Shakespeare's shadow looms large, but why is he significant in American culture? Why are politicians, writers, and ordinary people writing about Shakespeare and using him to support their ideological positions? In this thesis, I explore Shakespeare's role in America from the Revolution on through the twentieth century. I 
argue that Shakespeare is an integral part of American history and culture, as much as Emily Dickinson, F. Scott Fitzgerald, or any other American literary figure, as evidenced in how he fits into our culture, and how Americans have used Shakespeare throughout the centuries. In this thesis, I will focus on how these Americans utilized Shakespeare's plays. While specific plays and Shakespeare's texts will be analyzed, I will also follow the literary history of later writers in response to these plays, as a sort of literary history of reception. This means analyzing later pieces by Americans for what they tell us about attitudes toward Shakespeare and his drama. I further argue that this is made apparent in how Shakespeare was used by Americans to further their own ideological agendas in the public sphere, particularly regarding government, education, and race.

My first chapter will focus on the American revolution and the early Republic. During the American Revolution, soldiers on both sides were drawn to Shakespeare's plays. For the American soldiers, this was because they were still essentially British. Shakespeare was greatly admired by Founding Father John Adams, who during the early years of the United States, looked to Shakespeare for guidance and recommended Shakespeare's history plays and great kings as models for the well-structured republic he hoped this country would become. However, towards the 1820s and ' 30 s, America began to seek its own identity separated from Britain, an identity with racial tensions at the center of it. In the chapter, I will argue that the reason Shakespeare is prevalent in American culture is because America started out as an English colony, and that race relations were essential to the formation of an American identity. 
My second chapter will explore how Shakespeare's prominence in America endured during the Civil War era, for both the North and the South. Shakespeare often wrote about the horrors of civil wars in his history plays and in Julius Caesar, so these sentiments were shared by the Americans of this time. Whether Union or Confederate, north or south, Shakespeare loomed large in the time of this fractured nation. The reason was that the people of the north and south could both look to Shakespeare as a figure of rhetorical authority as he had already existed in this country long before the dissolution of the union. Mary Preston, a Confederate sympathizer, in her book Studies in Shakspere wrote essays on Shakespeare's plays, and her analyses will be of special interest in this chapter.

Following on the themes of the second chapter, my third chapter will be a look at President Abraham Lincoln and his assassin John Wilkes Booth. President Lincoln was a big fan of Shakespeare's plays. So, it is ironic that not only was he assassinated by a Shakespearean actor, but also that John Wilkes Booth used Shakespeare's words to justify his actions. Booth was very familiar with Shakespearean roles, but none of them he identified more with than Brutus in Julius Caesar. At the end of his defense of his assassination of Lincoln, Booth evoked Brutus. This chapter will analyze Lincoln's love for specific plays and verses, how that may have factored into Booth's characterization of Lincoln, as well as a critical look as to how Booth saw in Shakespeare the justification of his crime.

The final chapter will view how Shakespeare remained relevant in the twentieth century to promote both progressive and reactionary causes. The country, now over a 
hundred years old, had other uses for Shakespeare as more people from foreign lands attempted to immigrate here. This chapter will have special focus on Shakespeare's importance to the English language, and how that made Shakespeare useful in the education of those newly arrived here in order to promote "American culture." In this sense, Shakespeare has become yet another tool of white supremacist and xenophobic ideology.

My main argument is to show how Shakespeare's status as an author in America was used through ISAs to promote ideological agendas, particularly white supremacy and racism. Though other ideological positions will be examined such as the effects of war and antifascism, the issue of race is the most common theme throughout America's history, and Shakespeare was often looked to for justifications and promotions of such bigotry. Another goal of this thesis is to take a critical look at our own views on authority and Shakespeare. As Richard Delgado and Jean Stefancic write, "If contextualism and critical theory teach anything, it is that we rarely challenge our own preconceptions, privileges, and the standpoint from which we reason" (73-74). I wish to challenge authoritative power with this thesis, not just those "honorable" people that use Shakespeare, but the name of Shakespeare itself. Perhaps it is time to take a chisel to this golden statue of Shakespeare that we have erected. 


\section{Chapter I}

\section{To You I am Bound for Life and Education}

Shakespeare and Shedding the Bonds of England

From the very beginning, Americans have enjoyed Shakespeare. Of course, America began as English colonies, and I will argue in this chapter that one of the major reasons why Shakespeare would be a celebrated author in America is because of this. The first Americans had considered themselves English at one point, so they continued English culture, Shakespeare included. Both sides of the Revolution performed Shakespeare to entertain the troops. The side that fought for King George III would often watch productions of Shakespeare's plays that glorify England's military conflicts of the past "including Richard III, King Lear, 1 Henry IV, and Macbeth" (Shapiro 5). This makes sense: what better way to raise moral among troops fighting for England's continued control of North America than to show plays by England's national poet that all end with British victory and/or the rightful ruler of England victorious? However, while this country would start as essentially another version of England, America would start to develop its own identity during the early nineteenth century, an identity, I argue, that was deeply connected to race. However, Shakespeare would not only remain within this new identity, but would also be used to promote it.

While our first president, George Washington, had staged an amateur production of Julius Caesar while in office (Westfall 221), our second president, John Adams, looked to some of those same history plays the British soldiers were watching for 
guidance for America. Shapiro notes that "in [Adams'] political writings he would cite as examples plays as wide-ranging as Macbeth, Henry VIII, and The Merry Wives of Windsor" (13), and Adams referred to Shakespeare as the "great Master of every Affection of the Heart and every Sentiment of the Mind as well as of all the Powers of Expression" (qtd. in Shapiro 13). Clearly by the start of this country, Shakespeare's role within the author function is secure. This view of Shakespeare being the greatest expresser of emotions and greatest thinker of all time has been carried over from England to this young America. The fact that this is an early leader, a Founding Father, expressing these sentiments and using a wide range of Shakespeare's works in his political writings is telling. If this is the opinions of one of our political leaders, surely this view will spread and be emulated by other hopeful politicians.

Adams' "Letter to John Quincy Adams," written to his son in 1805, after his time as president, during John Quincy's early political career, is an example on how he would blend Shakespeare with politics. He starts his letter talking about contemporary political issues such as Congress, the Napoleonic wars, and the impeachment of Associate Justice Samuel Chace, but then immediately segues into talking about Shakespeare. Adams specifically references the plays about the War of the Roses; the plays about the reigns of English kings from Richard II to Richard III. The reason he references these plays and mentions them to his son specifically, is because he says, "those Plays of the great Poet if they are to be read by any one, with a view to the Struggles between the Red Rose and the White Rose, that is to the Treachery Perfidy Treason Murder Cruelty Sedition and Rebellions of rival and unbalanced factions" (John Adams, "Letter to John Quincy 
Adams" 14). Adams looked to Shakespeare for guidance and recommended Shakespeare's history plays and great kings as models for the well-structured republic he hoped this country would become. He sees in those plays the total collapse of law that would occur if the "rival and unbalanced factions" would start fighting each other, in other words, the horrors of civil war. Adams' great concern is that this country would be torn apart by factionalism.

Adams looks to England in Shakespeare's plays, particularly in the Henry VI and Richard III plays, to show the dangers of factionalism. It is from those plays that the reference to "the Struggles between the Red Rose and the White Rose" comes from. In The First Part of Henry VI, Act II, scene 4, a disagreement between Richard Plantagenet of York and the Duke of Somerset got so heated among the other lords and nobles that they had to move to the Temple Garden because they were getting so loud. They could not resolve the issue through debate, so they have the following conversation:

YORK. Let him that is a true-born gentleman

And stands upon the honor of his birth, If he suppose that I have pleaded truth, From off this brier pluck a white rose with me. [He plucks a white rose.]

SOMERSET. Let him that is no coward nor no flatterer But dare maintain the party of the truth Pluck a red rose from off this thorn with me. 
Each of the nobles picked a red or white rose, but the conflict was not resolved. These would be the factions of the War of the Roses. The tensions between the two sides would grow and eventually turn into a war for the English throne, the white representing House York and the red representing House Lancaster. This war would dominate the other Henry VI plays and Richard III. Many lives would be lost, but in Shakespeare's plays it all started with a small disagreement in a garden among the gentry. This is Adams' fear, that the bickering among the early political parties will lead to a destructive conflict. Within Shakespeare's plays about England's past, Adams saw a prophecy for America's future.

One significant phrase in Adams' quote is when he writes that the plays "if they are to be read by any one" will see what he sees in the plays. This implies that there is a clear and correct way of interpreting those plays. That this is coming from someone of immense influence and power, a Founding Father and former president no less, adds weight to what he is saying. As Foucault writes, discourse is "considered precious and desirable" when it is "linked to the exercise of power" (Foucault, "The Discourse on Language" 218). This is someone from on high stating to the masses below how Shakespeare should be read. While nowhere does Adams mention race or culture in his piece, pushing a "correct" way to interpret literature is a common theme in postcolonial studies. In postcolonial theories, one way for the colonized to attempt to gain any form of

\footnotetext{
${ }^{1}$ All of Shakespeare's text cited is taken from The Norton Shakespeare, $3^{\text {rd }}$ ed., edited by Stephen Greenblatt et al.
} 
selfhood to the colonizers would be to interpret the colonizers' literature the way they do in Western countries. While in postcolonialism this was a futile move, as even if the colonized would interpret the literature as the colonizers do, the colonizers would still view it as incorrect since the colonized came from different cultural contexts than the colonizers (Klages 138-9), Adams is still following in this tradition. Adams was born an English citizen, taught English values, taught English ways of interpreting English literature. Now he is an American, but he is continuing to push the same view of the history plays that he was taught onto his son, who in turn may go on to teach it as well. He is pushing this English interpretation onto this American country. While at this point in time, Americans were mostly of English descent, the coming decades would slowly diversify America, and race would become a significant political topic. When it did, Adams interpretations would be there to push the "correct" reading of Shakespeare's plays onto a much wider populace of much wider origins than England.

Hypocritically, as Adams warns of the dangers of factionalism he is also a willing participant in it, as he warns his son of the danger if "a [Alexander] Hamilton or a [Aaron] Burr" should become president ("Letter to John Quincy Adams" 15). In other words, we cannot let this country be divided by party politics, particularly by those on the other side of us. Within this analysis of Shakespeare and the warnings of civil war is a secondary agenda of Adams: to attack his political rivals. He viewed his political enemies as more concerning than factionalism itself. If conflict did arise, it would not come from his side but theirs. They would tear this country apart, not us. Some things never change, as this type of partisan double standard is quite common today. What Adams (and many 
other politicians since him) is using is the concept of binary opposites, to define yourself as opposite of another (Klages 121). We are the opposite of them, and they are bad, therefore we are good. This is a dangerous mindset to have. While in Adams' case both parties are of the dominant, white, male culture, this type of thinking would be used to suppress minority groups throughout history.

It is significant to note how Adams views the country at this time. After discussing how England did its business during the time of the War of the Roses, namely how alliances with France and Scotland were formed, he comments on his own government: "Our Presidents and Governors have not yet Wealth enough to give Dowers with their Daughters to Bonapartes Brothers or Nephews, nor are they rich enough to demand Royal or Imperial Girls for their Sons" (John Adams, "Letter to John Quincy Adams" 14-15). I doubt any American today could imagine a president using their children to marry other countries' leaders' children in order to broker alliances. It is not hard to imagine a monarch doing this though. These sentiments are made more interesting by what Adams reported he said to George III in their first meeting when the former served as the first Minister to the United Kingdom in the 1780s. In his meeting with the king, Adams claimed to say, "I Shall esteem myself the happiest of Men, if I can be instrumental in ... restoring ... 'the old good Nature and the old good Humour' between People who, tho Seperated by an Ocean and under different Governments have the Same Language, a Similar Religion and kindred Blood" (John Adams, "To John Jay" 26). In this diplomatic meeting, Adams is appealing their shared history to the king, almost as if they are relatives, "kindred Blood" being the key phrase. He is saying to the 
king that our countries are virtually the same. My purpose in bringing this up is that Adams has not separated America from England just yet and aspires America to be like another England. While they were separate countries, their culture was the same, and that includes Shakespeare.

This recognition of England in America was not limited to Adams, even as time moves farther away from the Revolution. In the 1820s and '30s, both James Fenimore Cooper and Henry David Thoreau write about America's dependency to English culture. In his 1828 piece "Notions of the Americans," Cooper writes, "Speaking the same language as the English and long in the habit of importing their books from the mother country, the revolution effected no immediate change in the nature of their studies, or mental amusements" (58). Thoreau comments in his 1836 piece "Advantages and Disadvantages of Foreign Influence on American Literature" that "we whistle, to be sure, our national tune; but the character of our literature is not yet established, ours is still in the gristle, and is yet receiving those impressions from the parent literature of the mother Country, which are to mould its character" (Thoreau 67-68). Thoreau and Cooper agree that despite all that has happened, and all the years that have passed, America and Britain are virtually the same. This is supported by Alexis de Tocqueville's findings as he was exploring America around this time. In his Democracy in America, he notes, "Nearly all the great English works are reproduced in the United States. The literary genius of Great Britain still shines its rays in the depths of the New World's forests" (Tocqueville 538). I argue that this is significant for Shakespeare to be an American figure, because Shakespeare was England's national poet, and during this time that meant he was 
America's as well. Indeed, Tocqueville further writes, "There is hardly a pioneer hut in which the odd volume of Shakespeare cannot be found. I remember reading the feudal drama Henry $V$ for the first time in a log cabin" (538). While they were no longer British subjects, the Americans still retained aspects of British culture. Now, instead of hailing to a king, they hail to the chief.

That is not to say, however, that a distinctly American identity was not on the rise. Despite starting from the same cloth, there were small distinctions between America and England even from the beginning. As previously mentioned, the history plays were popular with the English forces during the American Revolution. These plays glorifying English history of military superiority were not what the revolutionaries went for their entertainments. No, the Americans preferred Coriolanus for their Shakespearean appetites. Jonathan Sewall, a poet and lawyer, wrote an epilogue for performances of the play for American soldiers (Shapiro 5). In his epilogue to the play, Sewall includes the passage, "Keep stern Coriolanus still in view, / Impartial justice steadily pursue, / And to each warrior give a warrior's due" (7). In Shakespeare's play, Coriolanus was a Roman soldier who is banished by the people and politicians. As he is banished, Coriolanus responds, "Have the power still / To banish your defenders, till at length / Your ignorance - which finds not till it feels, / Making but reservation of yourselves, / still your own foes - deliver you as most / Abated captives to some nation / That won you without blows" (Coriolanus 3.3.124-130). When Sewell wrote his epilogue in 1778, American soldiers were in dire straits. Shapiro notes that in some publications to the epilogue, Sewell included a footnote that stated that there was much frustration within the 
American army when the epilogue was written and performed (5). Many may have felt betrayed and mistreated, and that is why Coriolanus was popular to them. They saw themselves in Coriolanus. What happens in the play after Coriolanus is banished is that he joins Rome's enemy and comes within a hear of conquering Rome. For the early American soldiers, this play served as a warning to politicians and civilians not to mistreat their soldiers.

The writers in the 1820s and '30s also mention a distinct American culture apart from the English. The point of Thoreau's essay is to develop an American identity through literature, to shed the bonds of England off literarily, as well as literally. Cooper also mentions the differences between the English and Americans. Cooper sees Americans as being superior to the British "because the people, being less exaggerated in their habits, are less disposed to tolerate caricatures, and because the theatres are not yet sufficiently numerous (though that hour is near) to admit representation that shall not be subject to the control of a certain degree of intelligence" (60). The reason for America's superiority is because England was formed "in a course school" while America was formed "under the dominion of common sense" (James Cooper 60). Already in 1828, the stereotype of American's superiority complex and anti-intellectualism is alive and well. An American identity was blossoming, and an Americanized version of Shakespeare was arising as well.

Adams, Cooper, and Thoreau illustrate two important factors about early America that is critical to my thesis, that of America's ties to England, and the need to develop their own cultural identity through ideological engagements with Shakespeare. Of course, 
Shakespeare's status as one of the most significant authors of western literature would loom large in America regardless of its cultural origins. We still study Homer and Dante extensively despite not originally being a Greek or Italian colony. However, since we started out as an English culture, this made Shakespeare a cultural figure of America as well as a literary one, a figure already in place at the beginning to be molded into an American figure. Due to America and England sharing the same literary sources, Cooper concludes that "Shakespeare is, of course, the great author of America, as he is of England" (59), and Ralph Waldo Emerson goes as far as to refer to Shakespeare as "the father of the man in America" in 1850 (117). This mindset will influence other Americans as history unfolds.

Towards the 1830 s, America began to seek its own identity, an identity with race and slavery at the center of it. This is where John Quincy Adams comes into play. Adams was the son of John Adams. Like his father, Adams was also a major fan of Shakespeare. He also had an extensive political career, one that possibly even exceeded his father: he served as a foreign minister to various countries (including the United Kingdom) during his early career, was a senator, Secretary of State, our sixth president, and, rather than retiring after his time as president, served as a member of the House of Representatives for over fifteen years until his death in 1848 . He also was strongly opposed to slavery. Shapiro argues, "His antislavery was matched by few Americans: Adams famously attacked slaveholding from the floor of the House of Representatives, successfully defended African Americans before the Supreme Court in the case of United States $v$. The Amistad, and opposed war with Mexico and the annexation of Texas on the grounds 
that they would extend slavery and lead to civil war" (42). Clearly, this was a man that valued freedom.

It should come as no surprise that Adams wrote about Shakespeare, particularly Othello, a play where the protagonist is a black man, and race is a central theme. Given his abolitionist views, his 1836 piece, "The Character of Desdemona," comes to shocking conclusions. In the piece, Adams frames his opinion on how to view Shakespeare, that "the first and chief capacity in which I have read and studied him is as a teacher of morals" (43). While I do not agree with Adams' conclusion, this interpretation of Shakespeare is central to understanding his piece. Another point is that this piece shows that Adams learned the lesson his father was trying to teach him: that there is a "correct" way to read Shakespeare, as he writes on this interpretation of Shakespeare, "I further said, that in my judgment no man could understand him who did not study him preeminently as a teacher of morals" (43). What is the moral that Shakespeare is trying to tell us in Othello, according to Adams? "I have said the moral of the tragedy is, that the intermarriage of black and white blood is a violation of the laws of nature. That is the lesson to be learned from the play" (John Quincy Adams 52). For Adams, interracial relationships are wrong and unnatural, and he cites Shakespeare's play as evidence for this. The fact that the author Adams chooses to support his racist ideology is Shakespeare adds validity to his perspective. Shakespeare's status as an author was already secure in America at this point in history, and Adams is using Shakespeare consciously and deliberately so that Adams' views may appeal to a wider audience. 
Adams' major focus, as the title suggests, is on Desdemona, and he goes into a full-on attack on her. For Adams, it is Desdemona above all else who is to blame for the tragic outcome of the play. He writes, "My objections to the character of Desdemona arise not from what Iago, or Roderigo, or Brabantio, or Othello says of her; but from what she herself does" (John Quincy Adams 43). Why? Because she married a black man, which, according to Adams, is "unnatural" (John Quincy Adams 44). Not only is there no better example of blaming the victim, but I argue that Desdemona is the most guiltless in the play—and, in this view, Adams' own ideology leads him to misread Othello. Iago is the architect of this misfortune, the main force behind the tragedy, but even his pawns Othello, Roderigo, Emilia, and Cassio have far more blame than Desdemona. Othello is easily duped by him, trusting Iago over his wife, and is ultimately the one that murders Desdemona in the final scene. Roderigo follows Iago's orders in creating discord with Cassio twice (Othello 2.3 \& 5.1). Emilia steals the handkerchief Othello gave to Desdemona due to Iago's bidding, and it is the handkerchief that is the nail in the coffin to Othello's brainwashing (Oth. 3.3 \& 4.1). Even Cassio, although manipulated by Iago and Roderigo, made the choice to get drunk while on duty which would lead to his fight with Roderigo, demotion (Oth. 2.3), and Desdemona's pleading for forgiveness for him that would help fuel Othello's jealousy. However, I argue that the most relevant character from the play in relation to Adams' criticisms of Desdemona would be that of her father, Brabanzio.

Adams has similar racist and sexist views as that of Brabanzio. In fact, it seems to be Desdemona's treatment of Brabanzio that Adams take the most issue with: 
She absconds from her father's house, in the dead of night, to marry a blackamoor. She breaks a father's heart, and covers his noble house with shame, to gratify — what? Pure love ... ? No! unnatural passion; it cannot be named with delicacy. Her admirers now say ... that the color of Othello has nothing to do with the passion of Desdemona. No? Why, if Othello had been white, what need would there have been for running away with him? She could have made no better match. Her father could have made no reasonable objection to it; and there could be no tragedy ... The father of Desdemona charges Othello with magic arts in obtaining affections of his daughter. Why, but because her passion for him is unnatural; and why is it unnatural, but because of his color? (John Quincy Adams, 43-44)

While Brabanzio initially suspects that Othello had put a spell on Desdemona in order to seduce and marry her, Othello's and Desdemona's testimonies reveal that Desdemona fell in love with Othello after she knew about Othello's history, and that it was a mutual decision to marry (Oth. 1.3.52-188). After this, Brabanzio is left heartbroken and defeated and says to Othello, "Come hither, Moor. / I here do give thee with all my heart / Which, but thou hast already, with all my heart / I would keep from thee" (Oth. 1.3.192195). He then turns to Desdemona in much harsher language, "For your sake, jewel, / I am glad at soul I have no other child, / For thy escape would teach me tyranny, / To hang clogs on them" (Oth. 1.3.195-198). Brabanzio's last lines of the play are addressed to Othello: "Look to her, Moor, if thou hast eyes to see: / She has deceived her father, and may thee" (Oth. 1.3.289-290). The balance of blame has shifted, Brabanzio now views 
Desdemona as the guilty one, just as Adams does. Adams even cites Brabanzio's warnings to Othello as further proof of his points (John Quincy Adams 49). The main reason for Adams' condemnation of Desdemona seems to be that she did not honor her father, however Brabanzio has far more guilt than her. It was his warning that would begin to fuel Othello's insecurity and doubt that would lead to him committing atrocities. It was this insecurity and doubt that Iago exploited, but I argue that it was Brabanzio that lit the fuse. The father, who Adams relates to, is more to blame than his daughter.

Adams is not only racist in this piece but also shows off his nineteenth century sexism in his criticism of Desdemona. Adams' condemnation of Desdemona boils down to "she married a black man, dishonoring her father in the process." Yet, if Desdemona is guilty of anything, it is loving her husband so much that it made her ignorant of the monster he was being molded into. Just before she dies after Othello has smothered her, she has this exchange with Emilia:

DESDEMONA. A guiltless death I die.

EMILIA. Oh, who hath done this deed?

DESDEMONA. Nobody. I myself. Farewell.

Commend me to my kind lord. Oh, farewell!

[She dies.] (Oth. 5.2.120-122) 
Despite what Othello has done, killed her, she still loves him so much that she does her best to protect him as she is dying. Her only crime is that she is a victim of circumstance. I can think of few fictional characters who are more innocent than her.

The significance of Adams' piece is specifically because of his solid work in congress against slavery. That even in the staunchest of abolitionists, the bile rot of racism and bigotry stirs. This shows that Adams may have been motivated to end slavery for personal reasons, rather than because it was the right thing to do. A tenant of Critical Race Theory (CRT) is that elite whites are motivated by self-interest above all else, and when elite whites do promote progressive causes, it is only if there is some form of personal gain for them in doing so (Delgado and Stefancic 7). Adams may have supported the abolition of slavery because he thought it would be another accomplishment to pin onto his legacy. While Adams believes black people deserve equality under the law, that is where it ended. Adams did not believe that black people were truly equal to white people. That is why critical race theorists will argue that equality under the law is not equality, as people of color will still be discriminated socially (Delgado and Stefancic 22-24).

By the time of Adams' death in 1848, America had shed most of its ties to Britain, yet Shakespeare would stick around. A distinct American identity was in full bloom, and racial tensions were at the center of it. When John Adams was in power, America was virtually another England, however there was a desire to develop an American identity separated from England, and an early American identity was in place by the time it was Adams' son John Quincy in power, an identity deeply tied to issues of race. Britain had 
abolished slavery in 1833 , but by the 1850 s, the issue of slavery was coming to a full boil in America, and it was about to spill out of the frying pan and into the fire. John Adams' fears were realized as slavery would tear this country apart, and north and south would be at Civil War by 1861. In these times of hardship, Shakespeare would remain there, for Confederate and Union alike. 


\section{Chapter II}

\section{Now is the Winter of Our Discontent}

\section{Shakespeare, North and South}

During the American Civil War, a legend arose about Edward Heldon, who had been one of Shakespeare's pallbearers before immigrating to the new world and ultimately dying in 1618. He was supposedly buried in Fredericksburg. This was a falsehood, but Shakespeare's influence was so great in America that a legend arose about someone who may have associated with him. Frederick Wadsworth Loring wrote a poem about this legend in 1870, "In the Old Churchyard at Fredericksburg." Fredericksburg was also the site of a major battle during the Civil War, where thousands of Union and Confederate soldiers lost their lives (Shapiro 217). The poem is about death, how some are remembered after death and others are not, as well as how authority factors into legacy.

Throughout the poem, the speaker knows about the battle and the thousands lost at the site and how little they will be regarded compared to the pallbearer. Loring is very critical of this, and the second and third stanzas are the most revealing:

There in the churchyard at Fredericksburg

I wandered alone,

Thinking sadly on empty fame,

How the great dead are but a name,-

To few are they really known. 
Then upon this battered stone

My listless eyes did fall,

Where lay the bearer of the pall

At the funeral of Shakespeare.

Then in the churchyard at Fredericksburg

It seemed as though the air

Were peopled with phantoms that swept by,

Flitting along before my eye,

So sad, so sweet, so fair;

Hovering about this stone,

By some strange spirit's call,

Where lay a bearer of the pall

At the funeral of Shakespeare.

(Loring 218)

Loring's message is clear. Most people who die will not be remembered. Most of the thousands of men who died in Fredericksburg will not be remembered. But this guy will be remembered because he was the pallbearer at Shakespeare's funeral, allegedly. Loring does not even name him in the poem, but that does not matter. In fact, in the poem, Shakespeare is the only name given, and he never even went to Fredericksburg. It is the pallbearer's connection to Shakespeare that makes him more memorable than the thousands of others that died there, not his name, this "empty fame" that Loring mentions in the second stanza. The speaker is very aware of what happened here, mentioning the 
"phantoms" in the graveyard. Each stanza begins noting that this is in Fredericksburg, and each stanza ends mentioning the pallbearer. Shakespeare's status in America is so large at this time that a random person is more likely to be remembered than the soldiers in war just because that random person was allegedly associated with Shakespeare (Loring 217-19).

Shakespeare's prominence in America endured during the Civil War era, north and south. Shakespeare often wrote about the horrors of civil wars in his history plays and in Julius Caesar, so these sentiments were shared by the Americans of this time. Mary Preston, in her 1869 book Studies in Shakspere wrote essays on his plays. In her essay on Julius Caesar she wrote, "Who but our Shakspeare, - for England cannot claim him; he is the legacy of the whole civilized world, - who but our Shakspeare" (Preston 105). Whether Union or Confederate, north or south, Shakespeare loomed large in the time of this fractured nation. The reason I argue was that the people of the north and south could both look to Shakespeare as a figure of rhetorical authority, as he had already existed in this country long before the dissolution of the union. In this chapter, I will examine how Shakespeare became a major figure in American education, as well as analyze how Americans used Shakespeare in relation to the Civil War, with a specific focus on Mary Preston's book of analyses.

How was Shakespeare an American at this time? It has a lot to do with how the education system was set up. During the nineteenth century, Shakespeare was widely used to teach the English language in American schools, which was the basis for American education. According to Professor Ashley Thorndike in a 1927 address, 
"Shakespeare could be found in the grammars, readers, and books on elocution which flooded the country or could be heard from some itinerant elocutionist or lecturer. Schools of oratory were established where the main test of eloquence was furnished by passages from Shakespeare" (520). This was significant and very different to European education, 'The so-called 'dead languages,' Greek and Latin, which in Europe constituted the basis of elementary training, were not entirely ignored, yet were regarded as less practical, and hence less necessary" (Joseph Quincy Adams 432). Since Shakespeare was so prominent in American education, Americans were quite familiar with his works. Thorndike goes as far to claim that "you can't be president of the United States unless you have read Shakespeare" (521). Thorndike would also claim that due to Shakespeare's popularity in the U.S., "It is our schools that have elected Shakespeare the perennial ambassador between two nations" (522). Shakespeare was the basis for our education, and when the average schoolboy to the president is vastly familiar and connected to his works, then he practically is American. No other writer that came before this country's existence featured so prominently in American culture. Shakespeare was already well in place within the American education system by the time of the Civil War, there to help guide citizens in their speeches and writings on the war. What adds further significance to this development, as will be explored deeply in the fourth chapter, is that Althusser views the education system as the most powerful and influential ISA (103104).

Another reason why Shakespeare was very popular in America during the nineteenth century is because his tragic protagonists were so compelling and relatable to 
Americans during this time. As Lawrence W. Levine writes, "Shakespeare's characterslike the Davy Crocketts and Mike Finks that dominated American folklore and the Jacksons, Websters, Clays, and Calhouns who dominated American politics - were larger than life: their passions, appetites and dilemmas were of epic proportions" (40). Levine also adds that their individual responsibility or lack thereof connected with American audiences at the time:

However flawed some of Shakespeare's central figures were, they at least acted - even the indecisive Hamlet — and bore responsibility for their own fate. If they failed, they did so because ultimately they lacked sufficient inner control. Thus Othello was undone by his jealousy and gullibility, Coriolanus by his pride, Macbeth and Richard III by their ambition. All of them could be seen as the architects of their own fortune, the masters of their own fate. (Levine 40-41)

That is a major reason why Shakespeare's plays were far more successful during the nineteenth century than another well-regarded play like Sophocles' Oedipus the King, a play about being at the will of gods with no control (Levine 41). Due to these two factors, Shakespeare was America's as much as England's by the nineteenth century. In fact, when George Mackepeace Towle, an American consul in England, returned to America after the Civil War, he believed that Shakespeare was more popular here than in England (Levine 17). Indeed, by 1843, the curtain of the St. Charles Theatre in New Orleans 
"depicted Shakespeare in a halo of light being borne aloft on the wings of the American eagle" (Levine 23).

One celebrated American Shakespearean actor during the nineteenth century was Ira Aldridge. Aldridge was an African American born in New York City in 1807. In 1825, he would play Othello on stage for the first time (Shapiro 142). His performance as Othello was well received, although some critics had difficulty accepted a black actor performing Shakespeare (Shapiro 142). While Othello was considered Aldridge's greatest performance (Brown 144), he also had success playing some of Shakespeare's other characters such including Hamlet, Richard III, King Lear, Macbeth, and Shylock (Shapiro 142). William Wells Brown considered "Hamlet one of [Aldridge's] best characters" (145), and Aldridge's Shylock also received high praise for his sympathetic portrayal (Shapiro 142). Yes, Aldridge was a celebrated Shakespearean actor, in London that is. As Brown writes about Aldridge's history, "No qualities of the mind could compensate, in the eyes of the Americans, for the dark hue of his skin. The prevailing prejudice, so strong among all classes was against him. This induced his removal to England" (146-147). Aldridge was to return to the United States after the Civil War to finally play Othello on the stage in his birth country, but he tragically died in 1867 before he could do so (Shapiro 142). One of America's most talented Shakespearean actors never performed there in his time due to the bigotry of the nation.

If Aldridge had been allowed to perform in America during the Civil War era, he would have found much work as Shakespeare's populism in America was so high that the three hundredth anniversary of his birth was recognized and celebrated by some 
Americans even as the Civil War was still being fought. On April 23, 1864, at an event hosted by Ralph Waldo Emerson, Oliver Wendell Holmes delivered a poem about Shakespeare (Shapiro 190). In the poem, he praised Shakespeare, but ended it thusly, "In this dread hour of Nature's utmost need, / Thanks for these unstained drops of freshening dew! / O, while our martyrs fall, our heroes bleed, / Keep us to every sweet remembrance true, / Till from this blood-red sunset springs new-born / Our Nation's second morn" (Holmes 192)! At this time, the Civil War, America's "second morn," was still raging, and Holmes' son was a soldier fighting in it (Shapiro 190). Holmes is very aware of the bloodshed as he gives this poem about Shakespeare, and praises Shakespeare for keeping “every sweet remembrance true." What remembrance? A remembrance of why they are fighting, America. A reason why Shakespeare would become popular during times of war is because, in many ways, Shakespeare became an example of American pride.

Shakespeare also had the same status within the Confederacy for the same reasons, and once again Shakespeare's works would be used to promote someone else's views. In her book, Studies in Shakspeare, Mary Preston analyzed a selection of Shakespeare's plays, and while the majority of her analyses seem to be thorough critiques of the plays (at least for the time), there are clear indications that she was a Confederate sympathizer. She opens her essay on Macbeth describing courage, one of Macbeth's attributes before he murdered Duncan,

Courage always commands admiration, even from unwilling breasts. That action of a Confederate general on the bloody field of Manassas, seizing the colors of a retreating regiment, and by his courageous example rallying 
an army, and charging in person against the foe, is one of the memorable incidents of that memorable day, which can never be forgotten, or dwelt upon without a thrill of pride and pleasure at a bravery so becoming and so distinguished.

(Preston 13)

Manassas was the site of an early Civil War battle which was a victory for the Confederacy. The way she describes the actions of this Confederate general, Preston reminisces about the early success of the Confederacy with an air of nostalgia. Not even five years after its fall, the Confederacy is romanticized within American Shakespearean criticism.

That was just the tip of the iceberg as Preston has an "eyebrow raising," to say the least, opinion on Othello. Unsurprisingly, the end of her entry on Othello reveals her opinions on race:

In studying the play of Othello, I have always imagined its hero a white man. It is true the dramatist paints him black, but this shade does not suit the man. It is a stage decoration, which my taste discards,-a fault of color, from an artistic point of view. I have therefore, as I before state in $m y$ readings of this play, dispensed with it. Shakespeare was too correct a delineator of human nature to have colored Othello black, if he had personally acquainted himself with the idiosyncrasies of the African race. (Preston 71) 
Preston's final sentence is a declaration, “Othello was a white man" (71)! This is not only racist, but also is a horrible misreading of the text. Othello's race and otherness are frequently mentioned throughout the text. The first conflict in the play is the fact that Desdemona has married a black man. Literally in the first scene, Iago refers to Othello as "an old black ram," and a "Barbary horse" (Oth. 1.1.84 and 109, respectively). While Preston may argue that "old black ram" is Iago making Othello out to be a beast regardless of race, "Barbary horse" refers to a horse from northwest coastal Africa according to a footnote in The Norton Shakespeare (2087n9). There is no denying Othello's race. Preston's racism clouds her reading of the text. While Preston recognizes and respects Othello as a great character, her racism cannot allow her to respect a black character. By Preston's own analysis, Othello is a fantastic character. However, he cannot be black, as black characters cannot be fantastic characters in her opinion. The idea is ridiculous to her. This again hearkens back to CRT and postcolonial theories. No matter how similar the Other is to the dominant white culture, they can never be viewed as equal in the eyes of the white oppressors (Klages 138-39). It is impossible for Preston to see Othello as black because she cannot see black people as worthy of admiration as white people, therefore Othello must have been a white man.

Preston has some significant things to say about Richard III in connection to war and tyranny. In many ways, her world was the same as that in Richard III, a country in recovery just after a civil war. Richard III takes place in Shakespeare's first historical tetralogy detailing the reigns of English kings from Henry VI to the beginning of Henry VII and details the War of the Roses between the noble British houses of York and 
Lancaster. Preston beautifully describes this world in a passage about the length of a page in a half (129-30). At the end of that passage, Preston writes, "Such are the feelings of most men as the curtain falls upon the awful tragedies of civil war. They have witnessed its harrowing scenes, and they hope never to behold them again" (130). While Preston was on the losing side of the Civil War, she does not desire to fight it again. The cost was too great, too many have died and suffered, and the pain is still very fresh in Preston's and in many other American's minds. It is because of this sharing of post-civil war worlds that makes Richard III a suitable play to analyze and look to for guidance during this time.

While America in the mid-nineteenth century and England in Richard III were both in recovery, the play has grim warnings rather than solace for America. Preston mentions one of the negative effects of war, of those that participate in war, "There are men - shame to human nature that they must be classed as such - who, during time of civil war, rise to the position, but must, with peace, return to their native obscurity" (130). Preston is referring to Richard, one of Shakespeare's most famous characters, and among literature's greatest villains. In his famous opening soliloquy, Richard laments, "Now is the winter of our discontent / Made glorious summer by this son of York, / And all the clouds that loured upon our house / In the deep bosom of the ocean burièd" (Richard III 1.1.1-4). The war is over, and now peace reigns. Later on in the soliloquy, Richard says, "Why, I, in this weak piping time of peace, / Have no delight to pass away the time" ( $R 3$ 1.1.24-26). Richard hates peace, just as the monsters that Preston describes. In his play, since he has no purpose in times of peace, Richard murders all who stand in his way of 
becoming king and is nothing less than a tyrant. Preston details with contempt Richard's deeds, and when referring to Richmond's rebellion at the end of the play, Preston writes that Richmond "returns from his exile, at the head of an army, to release his countrymen from the dominion of a great criminal" (141). ${ }^{1}$ Clearly, Preston is not a fan of tyranny, and is using the play to warn America of the potential risk should one of these figures arise from the ashes of America to power. She specifically compares Benjamin Butler, a General in the Union army during the Civil War and politician after it, to Richard (Preston 131). Her point is clear: war-mongering tyrants have no place in America!

However, maybe that is not always the case, as Preston's analyses of other plays come to different conclusions on government power. Preston's writings about Coriolanus are not as explicit when it comes to her support of the Confederacy, but she may have an even worse ideological subtext in her analysis. Preston opens her piece mocking the idea that all men are created equal and concludes that this is a falsehood. While this is about Preston's racism, she even states that there is natural inequality among the "Caucasian race” (Preston 37-38). She goes further, "men are not 'created free.' We were born subjects to God's laws, slaves to 'Caesar's' decree, dependents on each other. Free! There are no animals made, by nature, by circumstances, by passions, such slaves as man" (Preston 38)! She connects this idea to Coriolanus by stating that Coriolanus was such a man above the rest (Preston 44-45). This goes beyond the Confederacy. Preston uses Coriolanus to support her positive feelings on authoritarianism. That Coriolanus was

\footnotetext{
${ }^{1}$ Emphasis added.
} 
a superior man betrayed by those who were inferior (Preston 44-46). While that is not my personal reading of the text, this reading has a lot of textual support. In his first scene, Coriolanus confronts a crowd of people who are protesting about food shortages and declares how much he despises them, referring to them as "scabs" (Cor. 1.1.157) and "fragments" (Cor. 1.1.213). He specifically says to them, "Who deserves greatness / Deserves your hate" (Cor. 1.1.167-68). When he is banished, that speech in which he talks about having "the power still / to banish your defenders," the part that may have resonated with Revolutionary soldiers, he begins talking to the crowd calling for his banishment, "You common cry of curs, whose breath I hate / As reek o'th' rotten fens, whose love I prize / As the dead carcasses of unburied men / That do corrupt my air: I banish you, / And here remain with your uncertainty" (Cor. 3.3.117-121). It should be noted that Coriolanus was running for political office, counsel, when he was banished by the people, so it makes sense why the people would not want a man like him with that kind of power. Unlike Othello, the evidence is there to support Preston's argument.

Preston saw in Coriolanus something that confirmed her worldview, one that was completely different than the one that the Revolutionary soldiers saw, but nonetheless had support in the text. In A Theory of Adaptation, Hutcheon details how the story of sixteen Carmelite nuns executed during the Reign of Terror in 1794, went through adaptations and adaptations of adaptations throughout the twentieth century. Each adapter had their own ideological and personal bend to the story (Hutcheon 95-106). Hutcheon explains, "The reasons for interpreting it as either a political allegory or a tale of spiritual and psychological redemption were deeply embedded in the individual histories of the 
adapters, as well as in the political movements in which they were writing" (106). It all depends on the time and place the story is adapted as Hutcheon adds, "Major shifts in a story's context—that is, for example, in a national setting or time period—can change radically how the transposed story is interpreted, ideologically and literally" (28). As time goes on, political values change, and a tale travels to different places and cultures, the story is adapted to suit that time and place. There can be major ideological differences between two works from the same place separated by only a few years (Hutcheon 144)! Shakespeare is no exception. Each generation has their own interpretations and adaptations of Shakespeare (Sanders 60). This is an example of what Hutcheon would call "indigenization." Indigenization is, in words that Hutcheon used to describe the term as it relates to adaptation theory, when "people pick and choose what they want to transplant to their own soil" (Hutcheon 150). While the Revolutionary soldiers saw Coriolanus as a story about the struggles and betrayals of a soldier, Preston saw the play confirming her worldview on superior human beings being destroyed by the inferior masses.

Preston also sees another exceptional leader worthy of her respect in another of Shakespeare's plays: the titular character in Julius Caesar. "Julius Caesar 'achieved' his immortality. It was not 'thrust upon him.' He was not born Fortune's child, but he became her conqueror," she begins and then proceeds to go on for about the length of a page about how Caesar was gifted with good looks, fantastic personality, and that "Caesar was not only a grand and great man; he was also a man capable of touching and winning the heart" (Preston 103-104). She clarifies that "Shakspeare introduced me to the 
real man," while other depictions of Caesar in other works of fiction and history failed, adding further significance to Shakespeare (Preston 104-105). It is at this point in the essay where the quote about "Who else but our Shakspeare" comes from.

When Preston sees the quality of politicians in her time compared with Caesar, she finds them significantly inferior. At one point in her critique, she calls out American politicians on being dishonest by comparing them to Caesar,

I wonder how many of the statesmen - or those so styled and esteemed of our day and nation are capable of speaking to public bodies the plain, unvarnished truth, without pausing to weigh personal consequences? The instances of this kind that adorn these latter days of American statesmanship, are few and far between. They would form as rare and as precious a collection as anything to be found in the British Museum. (Preston 108)

In the preceding section, she had quoted Caesar in the play, "Shall Caesar send a lie? / Have I in conquest stretched mine arm so far / To be afeared to tell graybeards the truth?" as an example of Caesar's virtuous truthfulness (Julius Caesar 2.2.65-67). Again, Preston shows a poor reading of the text. In Act I, scene 2, lines 220-280, Casca reports to Brutus and Cassius how Caesar was offered a crown three times by Mark Antony, refusing the crown all three times. After refusing the crown for the third time, Casca says that Caesar "perceived the / common herd was glad he refused the crown, he plucked me / ope his doublet and offered them his throat to cut" (JC 1.2.259-261), then "fell down in the 
marketplace, and foamed at the mouth, / and was speechless" in front of the people (JC 1.2.249-250). Later, in Act II, scene 2, Calphurnia has convinced Caesar to not go to the Capitol after receiving a vision of Caesar's assassination. Decius arrives to bring him to the Capitol, to which Caesar responds that he will not go. Calphurnia tells Decius to tell the senators that Caesar is sick, Caesar then responds with the quote that Preston cited on his truthfulness. However, Caesar changes his mind when Decius claims "the Senate have concluded / To give this day a crown to mighty Caesar" (JC 2.2.93-94). He had merely been pretending to not want the crown in Act I in order to make the people force it upon him, to solidify that it is their idea rather than his. The great irony is that in the middle of his great deception is his declaration that he is not a liar. No, Caesar is just as corrupt as the politicians then and now.

Being "honest" is not the only virtue that Preston finds in Caesar, as another virtue that Shakespeare included according to Preston is how Caesar has an "immovable integrity of opinion" (106). In the play, Caesar says, "I could be well moved, if I was as you [Cassius]; / If I could pray to move, prayers would move me. / But I am constant as the Northern Star, / Of whose true-fixed and resting quality / There is no fellow in the firmament" (JC 3.1.59-63), and Preston cites that quote for an example (106). Ignoring the fact that this again shows what a poor reader Preston is, as in the situation with the crown previously discussed shows that Caesar is not as "constant as the Northern Star," being fixed in your opinion and unmoving in your beliefs is a horrible and very dangerous quality to find within a leader and suggests that this person thinks that they are infallible. "Why would I change my opinion? I am never wrong. They must be wrong." 
However, it is telling that Preston finds it admirable that Caesar refuses to change his mind. As detestable as a democratic society may find this, it fits in line with Preston's authoritarian beliefs. We must put our faith in Caesar, he is a man that is a step above all of us. Caesar knows best. However, if this is the case, why is Caesar assassinated?

Preston finds a motive in the assassins, one quite common and expected in politics. According to Preston, "the motive of Cassius, the leader of the conspiracy, and other co-conspirators, is envy, or jealousy" (107). On this, Preston and I agree. Cassius and the others were envious of Caesar's power and wanted that power to wield themselves. Cassius and the conspirators were of the upper classes, and yet were subservient to Caesar. This was unacceptable, so they murdered him. Preston acknowledges this, "Patricians by birth, they found themselves overshadowed by one who had made himself their acknowledged master. Their light grew dim in the blaze of his glory" (107). However, there is a subtle difference between our analyses. Preston goes onto write, "No greater tribute could be paid to the genius of Caesar than the involuntary admission of his enemies, that only by death could Caesar be overcome; that while life lasted, his genius and valor were bound to make them subjects. The field was open to all contestants; but these conspirators felt they had no chance in a race against Caesar; therefore they meanly stabbed him in the dark" (108). Despite being of the same class, Cassius and the conspirators are lesser men to Caesar. They cannot beat Caesar in an election, so they "meanly" have to assassinate him according to Preston. This is where I strongly disagree with Preston. Caesar is not better than the conspirators, he is just as corrupt. The only major difference between Caesar and the conspirators is that Caesar has 
power and the conspirators do not. If Cassius and Caesar had switched places, the dichotomy would be the same.

It is very strange that Preston would adore Caesar and despise Richard III. I actually find many similarities between the two. Both are political figures at the end of civil wars. Richard III takes place after the War of the Roses, and the beginning of Julius Caesar takes place after Caesar's forces have defeated Pompey's, who was another Roman political figure. Both attempt to gain power the same way. Richard murders all that stand in his way to the English throne, and Caesar defeats his rival Pompey for more power. There are two scenes in Richard III that are eerily similar to Caesar's actions with the crown in Act I, scene 2 in Julius Caesar. In Act I, scene 2 of Richard III, Richard is trying to seduce the Lady Anne to be his wife. This is a tall order because Richard murdered her husband and father-in-law, so she hates him. Richard offers Anne an ultimatum: if she will not be with him, then kill him since she hates him so much $(R 3$ 1.2.149-169). After Caesar had refused the crown for a third time, he "ope his doublet and offered them his throat to cut" (JC 1.2.261). Richard even "lays his breast open" when he challenges Anne to kill him (R3 1.2.164-165sd). The other scene that is similar in Richard III is Act III, scene 7. In this scene, Richard has made himself appear to be a deeply religious man before the crowd. He, along with his accomplice the Duke of Buckingham, have spread a rumor that King Edward IV's sons are illegitimate. Buckingham along with a crowd of people have come before Richard and demand that he become king instead. Richard, playing the part of a humble man, refuses their demands twice before finally "relenting" to their demands. Both Caesar's and Richard's plans for 
achieving more power are to trick the people into thinking that it is the people's idea to give power to them. Caesar and Richard use the same deception.

Why did Preston find Caesar admirable and Richard detestable if they were so similar? The section in her essay on Richard III where she compares Richard to Benjamin Butler may reveal this (Preston 131). Butler was a general in the Union army during the Civil War, the Confederates' adversaries. With that all revealed, what Preston is really supporting is that authoritarianism is bad when they do it. When a Confederate citizen commits murder, it is okay, he is one of the good guys and must have had a great reason. When a Union citizen commits murder however, then they are a monster and must be destroyed. Preston does not care about tyranny as long as you share her ideology. Like John Adams, Preston is using is the concept of binary opposites. We are the opposite of them, and they are bad, therefore we are good. Here are why these types of double standards are very dangerous and must be recognized as such: Preston is using it to justify authoritarianism. The Union should not have absolute power, for they are bad. It is ok if we do it, however, as we are not the Union, we are not bad. As stated previously, this mindset is not exclusive to Preston, and indeed one may find examples within our own time within party politics, so it is important to recognize and expunge this concept when our politicians use it.

During the Civil War, both the Union and Confederacy continued to use Shakespeare to push their ideological positions. As Shakespeare was a significant part of American education, and his plays and characters were so relatable to Americans, many Americans would look to him as their messenger during the war. Loring used 
Shakespeare to point out the war's legacy, that many of the soldiers would not be remembered despite all that they gave. Holmes looked to Shakespeare to escape the horrors of war. Preston used her readings (and misreadings) of Shakespeare's text to justify her worldview, including her hypocritical opinions on authoritarianism. However, not all Confederates were as keen on a singular leader with immense power, nor did all Confederates admire Caesar. Just as the Revolutionary soldiers had a different reading of Coriolanus than Preston, there were also different interpretations of Julius Caesar within the Confederacy. In fact, perhaps the most famous Confederate had a completely different reading of Caesar, and took a far different action than critiquing the play in a book. In the next chapter, we look at the opinions of one John Wilkes Booth on the play. 


\section{Chapter III}

\section{The Noblest Roman of Them All}

Booth, Lincoln, Shakespeare

The protagonist of Julius Caesar is not the titular character, Caesar who dies in the middle of the play, nor is it Mark Antony who speaks the most famous lines in the play, the "Friends, Romans, countrymen, lend me your ears" speech (3.2.71). The protagonist of Julius Caesar is Marcus Brutus. It is Brutus who goes through a character arc, the primary viewpoint of the play is through Brutus, and it is Brutus who has the tragic fall. Preston has much to say about the character of Brutus in Julius Caesar, particularly that he was noble, something the other conspirators lacked. Due to his status, "In joining and directing the conspiracy, Brutus showed that spark of a noble nature, he could not see his crime in its true light, and execute it; but Brutus veils assassination with that vague and general sentiment - which sometimes expresses one idea, and, anon, an idea entirely the reverse - called Patriotism" (Preston 109). It is that noble nature that Cassius recognizes in Brutus, along with Caesar's relationship with Brutus that convinces Cassius to recruit Brutus (JC 1.2.301-306). Indeed, Brutus is the last one to stab Caesar when he is assassinated, and Caesar pays special significance to Brutus' role, uttering the famous line, "Et tu, Brutè?" after being stabbed (JC 3.1.78). Brutus being involved in the assassination adds some legitimacy to the conspiracy due to his status and relationship with Caesar. If even Caesar's own friend stabbed Caesar, then clearly there was something wrong with Caesar. 
In the play, Brutus is conflicted on whether to assassinate Julius Caesar for the betterment of Rome. He reluctantly decides that Caesar must be assassinated, and laments, “Oh, that we could come by Caesar's spirit / And not dismember Caesar! But, alas, / Caesar must bleed for it" (JC 2.1.169-71). Even after the assassination, Brutus is sure of his convictions, that he is in the right. Preston notices, "Though Brutus fell, ... some portion of his lost magnificence clung to him, to deceive, with it glitter, the undiscerning. He still wore the name of patriot, when delivering against his country the most fatal blow" (110). During his speech to the crowd following Caesar's death, Brutus says,

If there be any in this assembly, any dear friend of Caesar's, to him I say that Brutus' love to Caesar was no less than his. If then that friend demand why Brutus rose against Caesar, this is my answer: not that I loved Caesar less, but that I loved Rome more. Had you rather Caesar were living and die all slaves, than that Caesar were dead, to live all freemen? As Caesar loved me, I weep for him; as he was fortunate, I rejoice at it; as he was valiant, I honor him; but as he was ambitious, I slew him.

$(J C 3.2 .17-25)$

He sees himself as this tragic hero, a man forced to kill his best friend in order to save his country. He still loves Caesar, and there is a sense that he is rationalizing his deeds to himself as much as to the crowd, but this had to be done. 
It is that aspect of Brutus that John Wilkes Booth would relate to. In 1865, it is those lines, “Oh, that we could come by Caesar's spirit / And not dismember Caesar! But, alas, / Caesar must bleed for it" (JC 2.1.169-71), that Booth chooses to end his justification for assassinating President Lincoln ("Letter to the National Intelligencer" 197). In this chapter, I will examine Shakespeare's connection to both Booth and Lincoln, how each viewed and respected Shakespeare's works, how the specific lines Lincoln enjoyed may have hinted at his ideological positions, and ultimately take a critical look as to how Booth saw in Julius Caesar the justification for his crime.

Booth's "Letter to the National Intelligencer" was written as a defense of his crime with the intention of being published after the assassination was carried out. In his defense, Booth wastes no time revealing his opinions on the United States and slavery, This country was formed for the white, not the black man. And looking upon African slavery from the same standpoint held by the noble framers of our constitution, I, for one, have ever considered it one of the greatest blessings, both for themselves and us, that God ever bestowed upon a favored nation. Witness heretofore our wealth and power; witness their elevation and enlightenment above their race elsewhere. (Booth, "Letter to the National Intelligencer" 194-95)

Booth is a white supremacist, and he has a mindset commonly examined in CRT, "the idea that 'Americanness' itself is racially marked as white, and that this marking is accomplished by making all nonwhites into non-Americans-or into Americans with 
modifiers, as in African American and Mexican American” (Klages 121). For Booth and others with similar views, only white people can be real Americans as "this country was formed for the white, not the black man." Booth writes about how great he thought this country was when slavery was legal, but now that slavery is abolished, he no longer views the country the same way.

Referring to the Civil War, Booth states, "For four years have I waited, hoped and prayed for the dark clouds to break and for a restoration of our former sunshine. ... My prayers have proved as idle as my hope" ("Letter to the National Intelligencer" 194). Given the results of the Civil War, Booth laments the now, in his opinion, terrible state of the United States ("Letter to the National Intelligencer" 196-97). Previously in the piece, he wrote, "Many I know ... will blame me for what I am about to do, but posterity I am sure will justify me" (Booth, "Letter to the National Intelligencer" 194). Booth believes that he is correct in his opinions, that many share this opinion, that he must kill Lincoln, and that Booth will be celebrated because of it. Booth paints a picture of a man who wants peace, but no longer sees that as a solution, and in order for his nation to be better, he must kill another man.

That is the place of Brutus in Julius Caesar, and Booth recognizes it. In his defense, on the play, Booth includes, "When Cæsar had conquered the enemies of Rome and the power that was his menaced the liberties of the people, Brutus arose and slew him. The stroke of his dagger was guided by his love for Rome" ("Letter to the National Intelligencer" 197). Booth was a Shakespearean actor, and he felt very close to the character of Brutus. Booth chooses to end his letter with those lines from Julius Caesar, 
and "I stand with Brutus," and signs it, "He who loved his country better than gold or life, John. W. Booth" (“Letter to the National Intelligencer" 197). Booth egotistically sees himself as some sort of tragic hero in the same vain as his interpretation of Brutus.

It is important to note that there is some question as to how much of this was Booth's actual feelings. Before Booth assassinated Lincoln, he gave that letter to his fellow actor John Matthews, with instructions to publish it after Booth assassinated Lincoln. However, once the deed was done, Matthews feared for his life should he be discovered with this letter, so after reading it over a few times, Matthews burned the letter, much to Booth's disappointment. In 1881, Matthews reconstructed the letter from memory where it was published in the Washington Evening Star (Shapiro 193). While there is question to its validity given the fact that it is a reconstruction from memory by someone else who read it over a few times over fifteen years after its destruction, Booth would have been familiar with Shakespeare, particularly Julius Caesar. He performed as Mark Antony with his brother Edwin in the role of Brutus in a popular 1864 production in New York (Shapiro 193). It is likely that Booth did feel this way, and like many other Americans, used Shakespeare for ideological purposes, in this case to justify a political assassination. Americans would frequently use Shakespeare's plays to justify their worldview, and Julius Caesar was Shakespeare's most political play. While his fellow Confederate, Preston, found Caesar admirable, Booth does not. Booth's identification with Brutus suggests that he relates Lincoln to Caesar. Brutus assassinates Caesar, Booth assassinates Lincoln after all. Booth could have seen Lincoln as tyrannical. If that is the case, then Lincoln's favorite Shakespeare verses certainly support that characterization. 
It is of great irony that Lincoln himself was a fan of Shakespeare's plays. His love of the Bard was reported by his secretaries as well as his son, Robert (Shapiro 181). In his diary entry on August 23, 1863, Lincoln's secretary John Hay notes that Lincoln "read Shakespeare to me, the end of Henry VI and the beginning of Richard III till my heavy eye-lids caught his considerate notice \& he sent me to bed" (76). Lincoln is reported has being such a huge fan of Shakespeare that his fandom has become a part of his legend. In depictions of Lincoln, "References to Shakespeare almost inevitably pop up in the fictional and semi-fictional representations of Abraham Lincoln that have been appearing since at least the beginning of the twentieth century. Having Lincoln quote, cite, or discuss Shakespeare became a certificate of authenticity, a detail so well-known" (Anderegg ix). The only surviving written piece of Lincoln on Shakespeare is a letter he wrote to the actor James H. Hackett, who had played Falstaff in a production Lincoln saw. In his brief letter, Lincoln wrote,

Some of Shakespeare's plays I have never read; while others I have gone over perhaps as frequently as any unprofessional reader. Among the latter are Lear, Richard Third, Henry Eighth, Hamlet, and especially Macbeth. I think nothing equals Macbeth. It is wonderful. Unlike you gentlemen of the profession, I think the soliloquy in Hamlet commenting "O, my offence is rank" surpasses that concerning "To be, or not to be." But pardon this small attempt at criticism. I should like to hear you pronounce the opening speech of Richard the Third.

(Lincoln 182) 
Here we see that Lincoln is deeply familiar with Shakespeare's works, particularly when he comments on his preference to "Oh, my offence is rank" soliloquy to the most famous lines Shakespeare ever wrote, "To be, or not to be."

However, there is room for some concern given Lincoln's favorite lines and plays. "Oh, my offence is rank" is spoken by Claudius in Hamlet, the man who assassinated his brother for the Danish throne. In that soliloquy that Lincoln loves so much, one he would often recite to himself while in law school (Anderegg 41), Claudius laments, “Oh, my offense is rank, it smells to heaven; / It hath the primal eldest curse upon't— / A brother's murder" (Hamlet 3.3.36-38). Claudius does feel guilty for his crime, but also adds, "Forgive me my foul murder? / That cannot be, since I am still possessed / Of those effects for which I did the murder - / My crown, mine own ambition, and my queen. / May one be pardoned and retain th'offense" (Ham. 3.3.52-56)? Claudius wants to keep that which he has earned through his vile deeds. This is the soliloquy that Lincoln holds in high regard? A usurper who, though feels guilt for what he has done, is too cowardly to give up what he has won. It could be rather troubling for an elected president to enjoy the words of a corrupt leader who refuses to be held accountable for his criminal actions and refuses to give up his power.

In fact, Lincoln seems to have a thing for usurpers. Within Shakespeare's plays that he is familiar with, Lincoln thinks "nothing equals" Macbeth and that it is "wonderful," and as Shapiro adds "historians note how rarely Lincoln used superlatives like 'wonderful'” (181). In this play, Macbeth was a noble Scottish general and thane under King Duncan. However, this changes when he encounters the three witches in Act 
I, scene 3, who tell him that he shall "be king hereafter" (Macbeth 1.3.51). From there, Macbeth murders Duncan, becomes king, and slowly descends into paranoia, as her commits more crimes in a futile attempt to maintain his power. This is the play that Lincoln thinks is "wonderful." The opening soliloquy of Richard III that Lincoln would like to hear Hackett perform also raises concern. As previously covered in the second chapter, the opening soliloquy of Richard III reveals Richard to be a man who hates peace and is hellbent on taking the crown by any means necessary.

What does that say about Lincoln that his favorite plays are about, and his favorite lines are spoken by usurpers and tyrants? Was that why Lincoln ran for president, for his own power? Was that why he pushed so forcefully for the abolition of slavery? A tenant of CRT is that elite whites are motivated by self-interest above all else, and when elite whites do promote progressive causes, it is only if there is some form of personal gain in doing so (Delgado and Stefancic 7). Was the abolition of slavery all about Lincoln and his legacy? Does Booth, and those with similar ideological positions have a point?

In Lincoln's defense, while all those plays were about tyrants and corruption, they were also the plays that were generally very popular with Americans at the time (Anderegg 27). In regard to Claudius' soliloquy, a reason that Lincoln may have found it as compelling as he did may be due to the strong element of humanity found within Claudius. Claudius had depth and conflict within himself, and as Michael Anderegg argues, "Lincoln, whose love of Shakespeare had much to do, I believe, with the drama of men caught up in powerful emotions, found Claudius's immediate struggle with his conscience more compelling than Hamlet's generalized speculations on suicide [, the 'to 
be or not to be' soliloquy]" (43). David Bromwich clarifies this point, "Lincoln was deeply touched by the portrait of the mind of a politician who had committed great wrongs. He was not equally moved by the thoughts of a hero who reproached himself for doing too little" (162). Those sentiments, "a politician who had committed great wrongs," is interesting when considering Lincoln and his love of particular Shakespearean themes. Another plausible explanation for Lincoln's interest in Shakespeare's crooked rulers, as Anderegg also suggests, could be because of "Lincoln's crushing sense of guilt over the Civil War" (47). The plays that Hays mentioned in his diary entry, the Henry VI and Richard III plays, are set during the War of the Roses, a civil war. Lincoln was in the midst of his own civil war at the time, a war that Booth claims was caused by his election ("Letter to the National Intelligencer" 194), in which thousands of Americans died. It is quite possible that Lincoln felt responsible, or even guilty for the bloodshed that plagued the country at the time. Maybe, in some form of self-criticism, he related to these horrible politicians because of this, and that is why he enjoyed those plays.

However, Lincoln does not mention anything about Julius Caesar, and maybe Lincoln was not a Caesar to Booth's Brutus after all. Caesar and Brutus were good friends in the play, and Brutus still loved Caesar and said so during his defense to the crowd. Judging by what he says of Lincoln in his defense, that "the nomination of Abraham Lincoln four years ago bespoke war. His election forced it" (Booth, "Letter to the National Intelligencer" 194), Booth was never a supporter of Lincoln. No, Lincoln was not Booth's Caesar, America itself was. 
Booth writes a lot about his love for his country. He addresses this letter "To $M y$ Countrymen," and he also states the he has "loved the Union beyond expression," emphasizing that "I do not forget the heroic patriotism of our fathers who rebelled against the oppression of the mother country," referring to the Revolutionary War (Booth, "Letter to the National Intelligencer" 194). Clearly, Booth loved the country the way it was rather than what it was slowly becoming. He shares the same bigotry as the Founding Fathers and appeals to authority in order to justify his worldview. However, Booth later adds, "Four years ago I would have given a thousand lives to see her remain (as I had always known her) powerful and unbroken, and now I would hold my life as naught to see her what she was" ("Letter to the National Intelligencer" 196). For Booth, America was no longer great. Booth loved the country for how it was, but now sees the current state of the country as something immoral. Booth writes, "I love justice more than I do a country that disowns it" ("Letter to the National Intelligencer" 196). This is a parallel to Brutus' statement on Caesar, "Not that I loved Caesar less, / but that I loved Rome more" (JC 3.2.20-1). Booth had loved this country, but if there is any chance to save it, he must kill its highest representative, his country's president. Booth reveals in his closing remarks that (in his opinion) "If the south is to be aided it must be done quickly. It may already be too late" ("Letter to the National Intelligencer" 197). Ultimately, he wants to save his country by hurting it.

Booth concludes, "When a country like this spurns justice from her side she forfeits the allegiance of every honest freeman, and should leave him untrammeled by any fealty soever to act as his conscience may approve" ("Letter to the National 
Intelligencer" 194). Booth must have considered himself an "honest freeman" in order to do these horrible acts to his country. This is actually similar to how Brutus is described in Julius Caesar. Antony follows Brutus' speech to the crowd in Act III, scene 2. In his speech, Antony does refer to Brutus as "an honorable man" several times, but it is ironic and sarcastic, for what kind of "honorable man" do such a thing to someone he claims to love? Just as they disagreed on Caesar, Booth and Preston disagree on Brutus. For Preston, "Brutus was the greatest traitor who ever lived; a traitor to good government; a traitor to friendship; a traitor to his benefactor" (113), sentiments that Preston and I are in agreement on. Brutus was not the hero that Booth envisioned, he was a man easily manipulated by others to serve their own ends. Certainly that makes Brutus sympathetic, but he is far from a hero worthy of respect. Brutus, no matter what Booth may have believed, made Rome worse rather than better. The assassination he participated in sparked another civil war in Acts IV and V, and after his and Cassius' defeat, one of the victors, Octavius, would become Augustus, the first Roman Emperor. The very thing Brutus was trying to prevent came to pass despite, and perhaps even because of his actions. Likewise, Booth's actions did not save the south as he may have intended, but may have even delayed reconstruction, slowing the healing process even more. It did not rally the south, it only made them appear more traitorous. In this regard, Brutus is a cautionary figure rather than one worthy of emulation.

However, Booth is not even Brutus. Booth may have realized this in the end, as while he was hiding after the assassination, in his final diary, his final sentence is "I do not wish to shed a drop of blood, but 'I must fight the course' Tis all thats left me" ("John 
Wilkes Booth's Diary: Zekiah Swamp and Nanjemoy Creek, Charles County, Maryland, 17 and 22 April 1865" 155). This is an allusion to a Shakespearean character, but it is not Brutus, it is Macbeth. In Macbeth, as Dunsinane is surrounded by Macbeth's enemies, Macbeth declares, "They have tied me to a stake. I cannot fly, / But bearlike I must fight the course" (5.7.1-2). Just like Macbeth, Booth realizes that he cannot escape unless he kills literally everyone in his way, an unlikely outcome. In the end, Booth realizes that he is not his conception of Brutus, but the vile murderer Macbeth. A key word that Macbeth says is "bearlike." Rather than the noble hero he envisioned, Booth is this pathetic, animalistic man cowardly hiding from justice. He realizes that there is no honor in killing someone, only condemnation. As Booth himself concludes, "Tis all thats left me."

Shakespeare had touched the lives of both the president of the United States and his assassin. Lincoln was a great admirer of Shakespeare; Booth had seen in Shakespeare the justification for a horrible crime. Booth had used Shakespeare to push his ideological position, as what other Americans had done before him. In the authority of Shakespeare, Booth saw a great ideological use for him: if Shakespeare shows that it is ok to commit a political assassination then I should be all set. America would go through many changes in the decades following Lincoln's assassination. Despite the Union winning the Civil War and slavery being abolished, race remains a contentious issue in America, especially as more and more immigrants come into the country as the twentieth century approaches. In the following century, the golden statue of Shakespeare would remain to be used by Americans. 


\section{Chapter IV}

\section{Brave New World That Has Such People In't}

\section{Shakespeare in the Dawn of the Twentieth Century}

The twentieth century brought many modern innovations into America and the world, and yet Shakespeare remained. The country, now over a hundred years old, had other uses for Shakespeare as more people from foreign lands attempted to immigrate here. While this was a chance at a new life for many of these immigrants, for many of the people already living in America, this was a major threat to their country. In this chapter, I argue that Shakespeare's importance to the English language within the education system would make him a useful tool to be used by Americans on those newly arrived here, a tool that would be used as a weapon to promote "American values," in other words white supremacy, American imperialism, and xenophobic attitudes. However, I will also examine how some other Americans used Shakespeare to promote more inclusive and progressive causes.

There is precedent for Shakespeare's use as a tool in colonialism in the mid-1800s with the Native American Maungwudaus. Maungwudaus, along with many other Native Americans, was indoctrinated into white American culture, became a Methodist minister, an interpreter and translator, and even took an English name, George Henry. In the late 1840s, Maungwudaus and other Native Americans toured Europe, performing "various tribal customs" for white audiences. On February 5, 1848, Maungwudaus visited 
Stratford-upon-Avon, Shakespeare's hometown and resting place. While there, he reportedly published a poem, "Indians of North America" (Shapiro 60). The poem reads,

\section{Indians of North America}

Heard the name that shall not decay, They came and saw where he was born, How great is the sound of his horn

They respect and honor his grave

As they do the grave of their brave;

Rest thou great man under these stones,

For there is yet life in thy bones.

Thy Spirit is with Mun-nid-do

Who gave thee all thou didst do:

When we are at our native home

We shall say, "We have seen his tomb."

(Maungwudaus 61)

Throughout the poem, Maungwudaus praises Shakespeare. The lines "Rest thou great man under these stones, / For there is yet life in thy bones" suggests that Maungwudaus believes that Shakespeare is immortal and will always be celebrated. The speaker states in the second line of the poem "Heard the name that shall not decay," indicating that Shakespeare's name will not fade from history. These lines echo a line in Ben Jonson's introductory poem to the first edition of Shakespeare's collected plays, 1623's $M r$. 
William Shakespeare's Comedies, Histories, \& Tragedies (more commonly referred to as the First Folio), which states "[Shakespeare] was not of an age, but for all time" (line 43)! Maungwudaus clearly had a great respect for Shakespeare, but the reason he went to visit his grave was because he was performing his tribal customs for white audiences in Europe for their entertainment.

It should be noted that this is the only piece written by a Native American in both of Shapiro's and Rawlings' collections, and it is a piece written by a Native American who was colonized. Maungwudaus was colonized by white Americans who used "Foucauldian mechanisms" and "ideological apparatuses" to "instill in the colonized a desire to become a Western subject — and to welcome the colonizer's takeover" (Klages 137). With Maungwudaus, the white Americans were quite successful. In postcolonial studies, Maungwudaus would be classified as a "subaltern," which is "the native who buys into the colonizer's ideology and does what she or he is told to do by the colonizers in order to become a self/citizen/civilized, and yet is never recognized as such by the colonizers" (Klages 137). Maungwudaus has bought into American culture, even going so far as to take an English name, and yet he is paraded around Europe doing his tribe's customs for the entertainment of white people. Through colonization, Maungwudaus became a tool for white supremacy. Would Maungwudaus had enjoyed Shakespeare if he had not been indoctrinated into white culture? Perhaps, perhaps not, but what is clear is that Shakespeare is tied to white culture, and may and will be used as a tool for white supremacy, just as Maungwudaus has. In the poem, Maungwudaus is speaking directly to the "Indians of North America" to come and pay respects to Shakespeare's grave. His 
conclusion to the poem is that "When we are at out native home / We shall say, "We have seen his tomb."' When he and his fellow Native Americans come back, they are going to spread this message around. As stated in the introduction, Western books such as Shakespeare's works were often tools of colonization (Klages 138). In this way, what Maungwudaus is really saying to his fellow Native Americans when he implores them to see Shakespeare's grave is to "buy into the white culture as we have. It is amazing!"

Henry Cabot Lodge was one of these Americans who would wield Shakespeare to promote American white supremacy. Lodge served in the House of Representatives from 1887-1893, then served as a senator from Massachusetts from 1893 until his death in 1924, fitting the definition of a career politician. In his 1895 essay "Shakespeare's Americanisms," Lodge addresses English criticisms of how American's now spoke English or, in other words, “Americanisms." Lodge scoffs at the English's criticisms of Americanisms because (according to Lodge), "The language which these people [the first English settlers] brought with them to Virginia and Massachusetts, moreover, was ... the language of Shakespeare, who lived and wrote and died just at the period when these countrymen of his were taking their way to the New World" (258). Shakespeare spoke 'Merican apparently. Lodge is making the English Language as authoritative as Shakespeare because English was "the language of Shakespeare."

To help support his point that Shakespeare used Americanisms, Lodge cites various examples from Shakespeare's texts. One of the examples is the use of "well" as an interjection in the line from Hamlet "Well, good night" (1.1.9), which apparently was not used by the English in the 1890s, Lodge even writing that the English would suspect 
a speaker of being American if they used well in this way (258-59). Lodge finds examples of American slang in Shakespeare's plays, such as to be "square," meaning to be fair or honest in American usage, which Lodge finds within lines in Timon of Athens (5.5.36), and Antony and Cleopatra (2.2.196), to further prove his point (262-63). Lodge uses this to throw a few jabs at the English, such as "This is not remarkable, but it is passing strange that words not only used in Shakespeare's time, but used by Shakespeare himself, should have lived to be disdainfully called 'Americanisms' by people now living in Shakespeare's own country" (258). Lodge further argues that the English should not criticize Americans for speaking a different version of the English language especially since these Americanisms "may have served the greatest men who ever wrote or spoke the language" (264). According to Lodge, when all is said and done, we all speak the same language, but the greatest writers and speakers would often use our uses of the language. Lodge simultaneously calls for peace, and yet still asserts American dominance. The word "English" has a multitude of meanings such as the language, literature, the country and its people, but most importantly for postcolonialism, "what has been claimed by England as belonging to English culture" (Klages 131). In this essay, Lodge is taken American ownership of the thing England arguably values the most: the English Language. While we both speak the same language, it is our version that Shakespeare uses.

I should note that I have no idea how correct Lodge is in his notions that Shakespeare used Americanisms. I am far more interested as to why Lodge feels this is important. Lodge also dedicates space to praising the English language: "The usage of the 
best writers, and of the best-educated and most highly trained men for the spoken word, without regard to where they may have been born or to where they live, is the only possible standard for English speech" (256). However, among these seemingly immature jabs between English-speaking peoples and hyperbolic praise of the English language, there is a darker intent. The phrases "best writers and of best-educated" and "without regard to where they may have been born or to where they live" reveal Lodge's white supremacist, linguistically imperialist ideological agenda. The use of the English language is a topic deeply explored in postcolonial studies (Klages 131). In his introduction to Lodge's piece, Shapiro highlights Lodge's goals as a politician, that being restrictive immigration policies and strong imperialist policies (254). Lodge also writes in his essay:

It is quite possible to have Tuscan Italian or Castilian Spanish or Parisian French as the standard of correctness, but no one has ever heard of "London English" used in that sense. The reason is simple. These nations have ceased to spread and colonize. They are practically stationary. But English is the language of a conquering, colonizing race, which in the last three centuries has subdued and possessed ancient civilizations and virgin continents alike, and whose speech is now heard in the remotest corners of the earth. (Lodge 255-56)

Lodge sees English has a weapon for Anglo-American imperialism. The use of the word "conquering" is quite alarming, but telling. In the following passage, as in the previous one, Lodge identifies the English language with the Anglo-American race, "Like the race, 
it has shown itself capable of assimilating new elements without degeneration. It has met new conditions adapted itself to them, and prevailed over them" (256). Shapiro notes that "Lodge had strong views about what it meant to be an American and considered education and the English language as essential to 'Americanizing' immigrants, which for him was crucial to the well-being of the nation" (254). That is why all this silliness about "Americanisms" is very serious to Lodge, because the English language is used by Americans as a weapon against what he sees as a major threat to the country, the Other. In his call for peace between the English and Americans in the fight for who speaks the superior version of English, Lodge writes, "It is much better for all who speak it to give their best strength to defending it and keeping it pure and vigorous, so that it may go on spreading and conquering, as in the centuries which have already closed" (264). Lodge would rather unite the English with the Americans in order to literally conquer the nonEnglish speaking world. English, and by extension Shakespeare, are a part of imperialist and white supremacist campaigns.

Lodge's views would be echoed over forty years later. In the late 1920s and early 1930s, speeches delivered by Ashley Thorndike (1927) and Joseph Quincy Adams (1932, a descendant of the former presidents) would highlight how Shakespeare had become an American icon by that time. Adams was the first director of the Folger Shakespeare Library in Washington, D.C. During the opening of the library on April 23, 1932, he delivered the speech "Shakespeare and American Culture" (Shapiro 418). In the speech, he cites and seems to have been inspired by Thorndike's 1927 address "Shakespeare in America." Both speeches focus on the same topics and ideas and cover the same history. 
Thorndike and Adams see Shakespeare at the same status within American culture. Both equate Shakespeare in status to George Washington and Abraham Lincoln. Thorndike wrote, and Adams quoted "Washington, Lincoln, Shakespeare, they are three whom Americans universally worship, and you will not find a fourth of ours or any other nation to add to this trinity" (Thorndike 525; Joseph Quincy Adams 419). Washington and Lincoln are the two most famous presidents, people who I have no idea how or when I learned about them, but have been familiar with for as long as I can remember. That is how large their shadows loom, and to equate Shakespeare with them is a powerful and provocative statement. This seems a little far-fetched, or even insulting to suggest this depending upon how one views it, however, Adams gives a reason for why he sees it as this way in his opening,

In its capital city a nation is accustomed to rear monuments to those persons who most have contributed to its well-being. And hence Washington has become a city of monuments. Varied in kind, and almost countless in number, they proclaim from every street, park and circle the affection of a grateful American people. Yet, amid them all, three memorials stand out, in size, dignity and beauty, conspicuous above the rest: the memorials to Washington, Lincoln, and Shakespeare. Do we not feel that this is right? (Joseph Quincy Adams 418) ${ }^{1}$

\footnotetext{
${ }^{1}$ Emphasis added.
} 
The memorial to Shakespeare in Washington, D.C. that Adams is referring to is the Folger Shakespeare Library, originally conceived as "the Folger Shakespeare Memorial" (Shapiro 401). In Adams' quote, he includes Shakespeare as not only American, but among "those persons who most have contributed to [America's] well-being," and the passage ends with Adams asking the audience "Do we not feel that this is right?" Shakespeare has been fully appropriated by America from Britain by the early twentieth century.

The Folger Shakespeare Library is "the world's largest Shakespeare collection," and is located not in Stratford-upon-Avon, not in London, but in Washington, D.C., "only a block away from the US Capitol [Building]" ("Visit"). The library is among the memorials to Washington, Lincoln, as well as the other American icons in the city. In this literal sense, Shakespeare is equated to Washington and Lincoln in the capitol. Why is the largest collection of documents related to a British author located in the capital of the United States? This location was chosen specifically by oil magnate Henry Clay Folger to house the library. As Folger was collecting documents, "In England, ... he was repeatedly urged to leave his collection as a Shakespeare memorial at Stratford-on-Avon. This he declined to do. His final intentions as expressed in a letter of January 19, 1928, was 'to help make the United States a centre for literary study and progress"' (Whicher 405). This was not just a celebration of Shakespeare, this was also intended to educate Americans. Shakespeare was being used to turn Americans into intellectuals. After all, one of the major reasons for Shakespeare's status in America was how he factored into American education, as established in the second chapter. 
Shakespeare being within education is very important, especially its relationship to xenophobia and racism. Both Thorndike and Adams reveal their xenophobic and white supremacist beliefs in their speeches, although Adams' bigoted views are far more prevalent in his piece than in Thorndike's. Adams refers to the shared culture of America and Britain as "Anglo-Saxon," and comments on the "white man's" ability to conquer the "savages" in "a wild and totally uncivilized continent," referring to westward expansion (Joseph Quincy Adams 421-22). He is very blunt on his views on immigrants from nonAnglo-Saxon cultures, "They swarmed the land like the locust in Egypt; and everywhere, in an alarming way, they tended to keep to themselves, in the larger cities, in mining towns, in manufacturing centres, where they maintained their group solidarity ... America seemed destined to become a babel of tongues and cultures" (Joseph Quincy Adams 431). Adams dehumanizes immigrants, literally comparing them to a plague in the Bible. Adams has similar feelings to John Wilkes Booth of a unified white America at the exclusion of the Other. This is connected to postcolonial studies on the "nation." In Mary Klages' examination of Homi K. Bhabha's theories on nation and national identity in Literary Theory: The Complete Guide, she showcases that "the concept of 'nation' is built upon the exclusion, or even extermination of those who are described as not belonging to that nation" (136). Those excluded from the nation are blacks in Booth's case, and immigrants from Adams' case. Klages reports how Bhabha "cites the Serbian 'ethnic cleansing' as a horrific example of how far a nation is willing to go, in killing its inhabitants, to produce a unified national identity" (135). For Adams, the national 
identity is Anglo-Saxon and nothing else. At this point, Adams is calling for the death of the Other's cultures rather than the people themselves.

The solution to this problem would be found in education. As Thorndike lectures, "In the face of a huge and increasing immigration of people of foreign speech, and in the face of differences of religion, race, geography, and heredity, we were also determined that so far as he went each should be educated in just the same way as all the others" (520-21). Like Thorndike, Adams saw education as the solution to this immigration problem, "Whatever the racial antecedents, out of portals of the schools emerged, in the second or third generation, a homogeneous population, speaking the same language, inspired by the same ideals, exemplifying the same culture" (432). The reason English formed the basis of American education and not Latin and Greek was because "the child of foreign parentage needed to be taught the tongue of the country of his adoption" (Joseph Quincy Adams 432). Similar to Lodge, Adams is calling for the English language to be used to destroy other cultures so that the Anglo-Saxon culture may survive.

Education in America was used to promote and instill xenophobic, American exceptionalist, and white supremacist ideologies - ideologies still found within America today - and Shakespeare was a big part of this conception since he was at the center of American education. Adams fully and proudly admits this, "If out of America, unwieldly in size, and commonly called the melting-pot of races, there has been evolved a homogeneous nation, with a culture that is still essentially English, we must acknowledge that in the process Shakespeare has played a major part" (434). Shakespeare is used to 
assimilate the Other in order to promote the dominant white identity. Once again, Shakespeare is a tool for white supremacy.

These dangerous ideological perspectives being pushed through the education system, while disgusting, is not surprising. In his essay, Althusser writes, "What the bourgeoisie has installed as its number-one, i.e. as its dominant ideological State apparatus, is the educational apparatus, which has in fact replaced in its functions the previously dominant ideological State apparatus, the Church" (103-104). One of the reasons why the education system is an effective ISA is because it pretends to be objective, or in Althusser's terms "neutral" in ideology, while secretly indoctrinating students to the ruling ideology (105-106). Foucault views the educational system very similarly to Althusser as well, stating, "Every educational system is a political means of maintaining or of modifying the appropriation of discourse, with the knowledge and the powers it carries with it" ("The Discourse on Language" 227). In this way, white supremacy, xenophobia, and imperialism that Lodge, Thorndike, and Adams are calling for can be taught, learned, and passed on in the education system. If one is being taught to believe in these perspectives in school, they are unaware of it as they are being indoctrinated, as the educational system appears to promote objective facts and is ideologically "neutral."

There are other problematic ideologies contained in the addresses. American exceptionalism is found sprinkled within Thorndike's and Adams' pieces. Although Thorndike comments on the English roots and ties in America (514), both are also clear to mark America's distinctions and superiority to other nations. It should be noted that 
Thorndike delivered his address to the British Academy in London (Joseph Quincy Adams 419). Thorndike painted a picture of America for his British audience, one that emphasized the differences (as he saw) between the two countries: "The United States has always had a frontier, has always been subduing wild land, establishing civilizations anew. Even now our country is very unsettled compared with the lands of western Europe whence we came" (Thorndike 513). "We are a little bit tougher than you Brits, and that is what makes us 'Murican," is essentially what he is saying. He could not help but gloat as a Shakespearean scholar about how intimate Americans had grown to Shakespeare, "I suppose it is true that a first-class book on Shakespeare will find more critical students in the United States than in all the rest of the world together. An English, a German, or a French scholar will look to us for the bulk of approval or criticism" (Thorndike 524). This is textbook propaganda. It is as if Shakespeare as returned from the grave and has planted an American flag on British soil.

Adams echoes these claims that Shakespeare is more significant in America than in Britain: "Persons of wealth developed the mania for collecting Shakespeareana, and the steady flow of Folios and Quartos across the Atlantic began, until the majority of such treasures rested in America ... We may confidently say that today Americans at large are more familiar with the dramatist than are any other people on the globe" (Joseph Quincy Adams 434-35). As established, "Mr. Folger made it his life work to bring together all the books and other materials that might be serviceable to a student of Shakespeare, and he succeeded even beyond his hopes in forming what is undoubtedly the largest and richest collection of its kind" (Whicher 402-403). This goal would affect America's relationship 
with Shakespeare dramatically as George F. Whicher details in his piece about Shakespeare's rising presence in America and the Folger Shakespeare Library, "Shakespeare for America." Due to the efforts of Folger, as well as fellow Gilded Age industrialist Henry E. Huntington, "the United States has come abreast of Great Britain in establishing important Shakespeare collections for scholarly use; this after years of lagging behind" (Whicher 403). It is significant that two of America's most successful and wealthiest capitalists were taking Shakespearean documents from Britain to America. Perhaps by taking such a strong interest in Shakespeare, they were trying to educate other Americans that successful businessmen are well acquainted with Shakespeare. Whatever their intentions were, to Thorndike and Adams, because of Folger and Huntington's actions, it seems that Shakespeare is not just equally American as he is British, but is even more American than British now because American wanted him more. It is as if the American Revolution has been fought again, but this time, instead of land, Americans have taken Shakespeare from the British. The colonized have become the colonizers.

Americans viewing themselves as the imperial successors to England have been developing for a long time. In that poem Holmes delivers on April 23, 1864, while Holmes is talking about Shakespeare in relation to America, he is sure to connect Shakespeare and America to the world that Shakespeare came from. To open the poem, Holmes begins,

"Who claims our Shakespeare from that realm unknown,

Beyond the storm-vexed islands of the deep, Where Genoa's roving mariner was blown? 
Her twofold Saint's-day let our England keep:

Shall warring aliens share her holy task?"

The Old World echoes ask.

(Holmes 190)

In this opening stanza, Holmes has the old world such as "the storm-vexed islands of the deep," a possible reference to The Tempest, the Italian city of Genoa, and England inquire if Shakespeare shall be shared by "warring aliens" (America during the Civil War). This gives acknowledgement to where Shakespeare came from, but also claims that Shakespeare now belonged to America as well. Indeed, Holmes follows up with the opening line of the next stanza, "O Shakespeare! Ours with all thy past" (Holmes 191). Holmes is making an ideological connection to the old world. America is the successor of Western civilization, specifically England.

England was the leading imperial power in the nineteenth century. England had colonies in "North America, to Africa, to the Islamic world of the Middle East, to India, to Asia, to the West Indies, South America, and Polynesia" (Klages 131). In these colonies, England would pass down their culture, including Shakespeare, to colonize and assimilate the native inhabitants of their colonies (Klages 131-32). That is what happened to the Americans, but now it was America's turn in the driver's seat. As England's power and influence diminished, America's grew. In his address, Thorndike was saying to the English, "Americans have already taken Shakespeare. Next, we are coming for your power. And you cannot stop it." Now America would become the greatest imperial 
power, to continue in the tradition of seizing other people's lands and force English culture upon them; force Shakespeare upon them.

However, this is not the only ideological use Americans had for Shakespeare in the early twentieth century. While white Americans were using Shakespeare to promote white supremacy, Shakespeare was also used by other Americans to promote progressive causes. On October 19, 1943, Paul Robeson debuted as the first black actor to play Othello on Broadway (Sillen 452). His performance was so well received that civil rights activist and one of the founders of the National Associations for the Advancement of Colored People (NAACP) "W.E.B. Du Bois wondered in an editorial if a white actor would ever play Shakespeare's Moor again" (Shapiro 451). While he was a great actor and his performances were admired, Robeson was also highly involved in political activism. He was so outspoken that he caught the eye of the FBI, "and FBI informants reported that he was making political appearances while performing Othello on tour" (Shapiro 451). He was well respected by those on the left, particularly Samuel Sillen, "a prominent figure in the Communist literary movement of the 1930s and 1940s" (Shapiro 451). Sillen gave a glowing review of Robeson, writing of his performance that, "Paul Robeson's Othello is indescribably magnificent" (452), while also writing and quoting Jonson's poem, “That Shakespeare was not of an age but for all time has never been demonstrated more movingly on the American stage" (Sillen 457). In contrast to Preston in the previous century, Sillen writes on Othello's race: 'Shakespeare wrote about a black man, and the dramatic crux of the play is incomprehensible unless we recognize Othello is different in color and cultural conditioning from the Venetians whose army he leads" 
(Sillen 452). Sillen also commented that a black man playing Othello on stage in America was a blow against Jim Crow laws and segregated schools, as well as "a glorious standard raised by democratic America in defiance of Nazism" (452).

The first performance of Othello by a black man in America was a major development in race relations. In contrast to Maungwudaus, Robeson embraced Shakespeare not to submit to white supremacy, but to land a major blow against it. This was still a time when schools in America were segregated and America was at war against Nazi Germany. In the previous century, Ira Aldridge had to go to England to play Othello as black actors were not allowed to play Othello in America because of their race, and up until this point Othello had only been played by white people on stage in this country. Some, such as Preston, were arguing that Othello was white. While Robeson's success was a small step as America had (and still has) a long way to go, as Sillen puts it, Robeson's production "foreshadows the more civilized future" (453).

Robeson was not the only American around this time to be striking blows against horrible ideologies on the Shakespearean stage. Alarmed by the rise of fascism in Europe, Orson Welles staged one of the most famous productions of Julius Caesar at the Mercury Theatre in 1937. This production was staged in modern dress, so Caesar was dressed "in the type of military uniform affected by a Mussolini or a Hitler" (Whipple 442), although he is was more of a symbol than a man (Whipple 443). Welles subtitled the play The Death of a Dictator (Shapiro 441), and edited the play for a specific purpose, 
[Welles'] Caesar was the debate as to what could be done to keep the state from magnificent tyranny: Cassius was bitter, envious, resentful, while Brutus was intended to be a noble liberal. But the two were shown as friends who differ in outlook and sense of necessary action. Then, in their argument or hesitation, they are outflanked by a simple demagogue, Antony, who wins the crowd and becomes a more ruthless fascist than Caesar could have made. (Thomson 84)

This was becoming an increasing problem for America at this time. Across the pond, the rise of fascism in Italy and Germany were becoming harder to ignore. What was to be done about it? What kind of a threat did they pose? For Welles, this was a paramount subject. Years later, while reflecting back on the production in an interview, Welles said, "At that time fascism was the most important thing in our lives. An anti-fascist theatrical work was an important thing" (qtd. in Marienstras 153). While in a few years after Welles' production America would be at war against them and eventually win along with the Allies, at the time, the future was a mystery, and Welles was here to remind Americans that this tricky situation had to be well thought out before actions were made, and that it was best not to bicker amongst one another after actions were taken or else fascism may win all the same.

One of the most famous scenes in this performance is the death of Cinna the poet. In Act III, scene 3 of Shakespeare's play, Cinna the poet is mistaken by a mob as Cinna the conspirator who was among those who assassinated Caesar, and due to this is killed by the mob offstage despite his pleas that he is not the conspirator. Someone in the mob 
even comments after Cinna's denials, "It is no matter, his name's Cinna" (JC 3.3.32), also commenting after hearing that he was the poet, "Tear him for his bad verses, tear him for his bad verses" (JC 3.3.29-30)! Welles staged this scene with great effect, having Cinna enter alone whistling before confronted by the mob. After handing papers to the mob confirming his identity, he begins to walk away when confronted by another mob. He turns away but is confronted by another mob and with each turn another mob appears. As he pleas that he is Cinna the poet, the mob slowly closes in around him as the light fades, and he is swallowed up by the fascist monster (Whipple 445). Welles made many cuts to Shakespeare's text (Shapiro 441), at one point even considered cutting the role of Cinna the poet (Thomson 86), and I do not know if the lines of the crowd not caring whether Cinna was the guilty party or not was kept in, but I hope it was. Within a fascist system, it does not matter when a person is "guilty" or not. Whether you are the poet or the conspirator, the fascist mob devours everyone up just the same.

During the early twentieth century, Shakespeare had fully been accepted by America as one of its own. The Folger Shakespeare Library went up, and a physical symbol was now in place in the capital to remind Americans of Shakespeare's status. Shakespeare in the twentieth century was used both to promote white supremacy, and to fight against it. He has been used since the beginning as a guide on how to form our government, to becoming a Confederate supporter, to influencing a president's assassination, to fighting against fascism. By the early twentieth century, Shakespeare was as American as apple pie, and even Washington and Lincoln to some. With all this 
Jaroma 80

examined, only one question remains: how does this status still hold up in the $21^{\text {st }}$ century? 
Jaroma 81

\section{Conclusion}

The Fault, Dear Brutus, Is Not in Our Stars, But In Ourselves

Things are not as they once were with regards to Shakespeare and literary analysis. The Humanities are no longer seen as relevant as they were during the time of Thorndike and Adams. According to a 2017 survey conducted by the National Center for Education Statistics, the number of people majoring in the Humanities has sharply decreased since 1998, with the number of English majors specifically having fallen $49 \%$ since 1998 (Schmidt). Anti-intellectualism is on the rise and higher education itself is also not regarded as it once was, particularly among Republicans. According to a 2017 poll by the Pew Research center, while $55 \%$ of all American surveyed, regardless of political beliefs, believe colleges have a positive effect on society, only $36 \%$ of Republicans surveyed believed that college has a positive effect. That is an $18 \%$ decrease from the approval ratings in 2015, which coincidently (or not) was the year Donald Trump announced his candidacy for president of the United States ("Sharp Partisan Divisions in Views of National Institutions"). In his address, Thorndike states “you can't be president of the United States unless you have read Shakespeare" (521); yet I seriously doubt that that is the case in the twenty-first century as Trump cannot even quote or cite his own purported favorite book the Bible properly (C-SPAN).

However, some things have remained the same, as white supremacy is still a major problem. While many Americans may consider racism to no longer be a major issue in the United States, 
Studies show that blacks and Latinos who seek loans, apartments, or jobs are much more apt than similarly qualified whites to be rejected, often for vague or spurious reasons. The prison population is largely black and brown; chief executive officers, surgeons, and university presidents are almost all white. Poverty, however, has a black or brown face: black families have on average, about one-tenth of the assets of their white counterparts. They pay more for many products and services, including cars. People of color lead shorter lives, receive worse medical care, complete fewer years of school, and occupy more menial jobs than do whites. A recent United Nations report showed that African Americans in the United States would make up the twenty-seventh ranked nation in the world on a combined index of social well-being; Latinos would rank thirty-third. (Delgado and Stefancic 10-11)

So, any notion that racism is dead in the United States is a total falsehood. According to the FBI, over 50\% of hate crimes were committed by white people in 2017 (“Offenders”), and in a statement before the House Oversight and Reform Committee on June 4, 2019, the FBI stated "Individuals adhering to racially motivated violent extremism ideology have been responsible for the most lethal incidents among domestic terrorists in recent years" (McGarrity and Shivers). Another thing that has remained the same, although in a depleted sense, is that Shakespeare still appears in American ideologies, even in the era of Trump. 
In the summer of 2017, Shakespeare in the Park staged a production of Julius Caesar in modern dress, and the character of Caesar looked and acted like President Trump. Naturally, this caused some controversy (Beckett). There were protests from right-wingers, Shakespeare in the Park lost sponsorships (Beckett), a performance was even interrupted by right-wing provocateurs yelling things like "This is political violence against the right" and "You are all Goebbels" (Wahlquist and Beckett), and even Donald Trump, Jr. voiced concern and suspicion (Shaffer). The theatre defended their decision, stating, "Our production of 'Julius Caesar' in no way advocates violence towards anyone. Shakespeare's play, and our production, make the opposite point: those who attempt to defend democracy by undemocratic means pay a terrible price and destroy the very thing they are fighting to save" (Shaffer). Shakespeare in the Park continued in the long tradition of Americans using Shakespeare to push an ideological position. All of the drama over this production (pun intended) poses a deeper connection between Julius Caesar and Donald Trump, and while the message from the play I come to is different from the Shakespeare and the Park production, it is incredibly relevant to the present.

In many ways, the cases of Donald Trump and Julius Caesar have many parallels: there are problems within the governments in both America and Rome, both Trump and Caesar are controversial leaders of their respective countries, they are major causes for alarm in these countries, and there are government figures trying to find a solution to this problem in both cases. The common solution proposed in both cases is removing this figure from power, impeachment for Trump and assassination for Caesar. However, even 
if Trump is removed from power, it will not solve our problems, as it did not solve the problems in Rome when Caesar was killed.

One thing that is apparent in Julius Caesar is that Caesar's assassination merely delayed the rise of a tyrant. In the play, Antony immediately wins Rome's people to his side after Caesar's assassination, sparking a civil war which causes further death and suffering for the Romans, and he joins forces with Lepidus and Octavius to defeat Brutus and Cassius at the Battle of Philippi, leaving the three virtually in command of Rome in the end. Antony and Cleopatra, another of Shakespeare's plays set in Rome and Egypt after Julius Caesar, explores the tension and conflict between Octavius and the combined forces of Antony and Cleopatra for control of what would become the Roman Empire, Lepidus being deposed offstage in the middle of the play (Antony and Cleopatra 3.5). In yet another bloody and viscous war for the people, Octavius is victorious against Antony and Cleopatra by play's end, leaving him as sole ruler of the Roman territories. What is significant to note is that Octavius is almost exclusively referred to as "Caesar" in Antony and Cleopatra. In that sense, despite Brutus and Cassius' plot, Caesar rose to absolute power anyway. It did not matter that a potential dictator was killed, as another dictator rose in his place. The controversial leader was not the problem, they were the symptom of a corrupt system already in place.

To further explore this idea, one must look to the conspirators themselves. In the play, Brutus cites the reason for killing Caesar "not that I loved Caesar less, / but that I loved Rome more" (JC 3.2.20-21), as Brutus viewed Caesar as tyrannical and to the detriment of Rome (JC 3.2.21-25). However, the other main conspirator did not have 
nearly as noble reasons. Cassius states in conversation with Brutus, "I was born free as Caesar, so were you; / We both have fed as well, and we can both / Endure the winter's cold as well as he / ... This man [, Caesar,] / Is now become a god, and Cassius is / A wretched creature and must bend his body / If Caesar carelessly but nod on him" (JC 1.2.97-99, 115-118). While one could argue that Cassius is arguing for a more inclusive government instead of a dictatorship, after Brutus leaves, and Cassius is alone, Cassius reveals the differences between them: "Well, Brutus, thou art noble. Yet I see / Thy honorable mettle may be wrought / From that it is disposed. Therefore it is meet / That noble minds keep ever with their likes; / For who so firm that cannot be seduced? / Caesar doth bear me hard, but he loves Brutus. / If I were Brutus now, and he were Cassius, / He should not humor me" (JC 1.2.301-308). The real Cassius is revealed here, a deceiver who intends to manipulate a good man to help assassinate Caesar. Cassius wants to remove Caesar not because he sees Caesar as a threat to Rome as Brutus does, but because Caesar has the power over Cassius. His complaints reek of narcissism and envy. Cassius is basically saying, "What makes Caesar so special? We both were raised the same and came from the same class," leaving unsaid but implied "why should I not have the power instead?"

Cassius' role in Julius Caesar has major relevance to drama found within America's government during the Trump Administration. While I personally would rather have a Democrat as president, Nancy Pelosi and the House Democrats may not have the best of intentions. There was a lot of speculation as to why the Democrats waited so long to begin the impeachment process after retaking the House, despite all the 
evidence of illegal conduct by the Trump Administration, as well as to why they picked the time that they did to begin the impeachment process (Zurcher). That is the first major lesson I find in Julius Caesar, that the elites who are trying to remove the leader may not have the interests of the people in mind, but their own. It is these elites fighting for their own turn in the big chair that helps feed into this cycle of corruption and suffering.

The problems of racism, sexism, income inequality, and other forms of bigotry and suppression did not sprout up with Trump. As I hope my thesis has demonstrated, they have been here for a while. During the controversy with the Shakespeare in the Park production, many Republicans claimed that if Julius Caesar had been portrayed as being similar to former President Barack Obama, then the Democrats would be just as upset. As it turns out, there have been productions of Julius Caesar where Caesar was similar to Obama with no fanfare (Michael Cooper). While they were both done by different directors with different companies years apart, I like the idea of the cycling of Caesars given America's current predicaments. Part of Obama's appeal when he was elected in 2008 was that he was going to attempt to fix the damage done by the Bush Administration, "Change" literally being one of his campaign slogans. However, much of these proposed changes did not happen: there are still U.S. military campaigns tearing apart the Middle East, there is still a large divide between how the $1 \%$ and the $99 \%$ are cared for, and while Obamacare is an improvement over the previous healthcare system, millions of Americans still cannot afford health insurance. Obama ended up not being that radical after all, merely another retainer of the status quo. 
Obama was Caesar, Trump is Caesar. While I am not suggesting that all presidents are equally bad (it is my bias that Obama was certainly a better president than Trump), those same problems America is dealing with under Trump were happening under Obama as well. Removing the leader whether it be assassination, impeachment, or electing a leader from a different party than the previous leader is not going to solve anything because the leader is not the problem. It is the system that supports them that is the problem, this ideological system that we have bought into for far too long. In order to make America greater than it ever was, the whole system needs to be reformed. While I am not sure of specific changes, and these can and will be debated, it is going to take a lot more than a new leader if we are ever to start solving our societal problems.

The point of my analysis of Julius Caesar and Antony and Cleopatra is to demonstrate that we still need these Humanities courses that some think are irrelevant, and to remain educated if we are going to engage with authority critically. It is very important to continue to challenge authority whether that authority be Donald Trump, or Bernie Sanders. If we are going to topple terrible ideologies such as white supremacism and fascism, to engage with them critically, we will need to continue to learn how to look at literature, history, philosophy, and even Shakespeare through a critical lens. Maybe that is why Trump and his supporters antagonize college, because they realize that the best way to keep the system that rewards them so much afloat, is for the people to remain ignorant and impotent in the face of power.

It is funny, I have often compared myself to John Adams: we are both men from New England, short-tempered, a bit overweight, and share a belief in a strong, central 
government. However, I never thought that we would both look to Shakespeare for guidance on problems within the American government. I too have used Shakespeare to promote an ideological agenda in America. That is not to say that Shakespeare is some Nostradamus type. Far from it. Shakespeare does not hold the secret solution to every problem. As I have demonstrated in my thesis, Shakespeare can be read or misread to justify or promote almost anything, as this thesis provides five different interpretations of Julius Caesar alone. No, as my thesis shows, Shakespeare is an authority that welldeserves to be challenged as well. The golden statue of Shakespeare should be toppled, we should reject the concept of the author function as a way of thinking, whether that author be Shakespeare, Kate Chopin, John Milton, or Walt Disney. It places far too much authority on authors, and limits critical thinking. It should not be accepted that someone should be respected or even listened to as an intellectual just because that person is familiar with Shakespeare, as some have used Shakespeare to support some of the worst, immoral, and, to put it bluntly, idiotic ideologies such as white supremacy, fascism, and political assassinations in America alone. I am not suggesting that we should not read, study, interpret, and enjoy Shakespeare; again, far from it. I am only saying that Shakespeare is not a god, nor is Shakespeare the be all end all to intellectualism or literature. When it is all said and done, whether in America, Britain, or the rest of the world, Shakespeare is simply William Shakespeare the man, his works are his works, and his ideology is often not his but our own. 


\section{Work Cited}

Adams, John. "Letter to John Quincy Adams." Shakespeare in America: An Anthology from the Revolution to Now, edited by James Shapiro, the Library of America, 2014, pp. 13-15.

--. “To John Jay.” John Adams: Writings from the New Nation - 1784-1826, edited by Gordon S. Wood, the Library of America, 2016, pp. 24-28.

Adams, John Quincy. “The Character of Desdemona." Shakespeare in America: An Anthology from the Revolution to Now, edited by James Shapiro, the Library of America, 2014, pp. 42-53.

Adams, Joseph Quincy. "Shakespeare and American Culture.” Shakespeare in America: An Anthology from the Revolution to Now, edited by James Shapiro, the Library of America, 2014, pp. 418-435.

Anderegg, Michael. Lincoln and Shakespeare. University Press of Kansas, 2015.

Althusser, Louis. "Ideology and Ideological State Apparatuses: Notes towards an Investigation." Lenin and Philosophy and Other Essays. Translated by Ben Brewster, Monthly Review Press, 2001, pp. 85-126.

Beckett, Lois. "Trump as Julius Caesar: Anger over Play Misses Shakespeare's Point, 
Says Scholar.” The Guardian, 12 June 2017, https://www.theguardian.com/ culture/2017/jun/12/donald-trump-shakespeare-play-julius-caesar-new-york. Accessed 22 June 2017.

Bloom, Harold. "Shakespeare, Center of the Canon." The Western Canon: The Books and the Schools of the Ages, Riverhead Books, 1994, pp. 43-71.

Booth, John Wilkes. “John Wilkes Booth’s Diary: Zekiah Swamp and Nanjemoy Creek, Charles County, Maryland, 17 and 22 April 1865." "Right or Wrong, God Judge Me": The Writings of John Wilkes Booth, edited by John Rhodehamel, and Louise Taper, University of Illinois Press, 1997, 154-157.

--. "Letter to the National Intelligencer." Shakespeare in America: An Anthology from the Revolution to Now, edited by James Shapiro, the Library of America, 2014, pp. 193-197.

Bromwich, David. "Shakespeare, Lincoln, and Ambition.” Moral Imagination, Princeton University Press, 2014, pp. 160-179.

Brown, William Wells. "Ira Aldridge." Shakespeare in America: An Anthology from the Revolution to Now, edited by James Shapiro, the Library of America, 2014, pp. $142-147$.

C-SPAN. “Donald Trump: 'Two Corinthians...' (C-SPAN).” YouTube, 18 Jan. 2016, https://www.youtube.com/watch?v=8EIgHsGZAmk. 
Clinton, Bill. Forward. Shakespeare in America: An Anthology from the Revolution to Now, edited by James Shapiro, the Library of America, 2014, pp. xvii-xviii.

Cooper, James Fenimore. "Notions of the Americans." Americans on Shakespeare: 17761914, edited by Peter Rawlings, Ashgate, 1999, pp. 58-60.

Cooper, Michael. "Why 'Julius Caesar' Speaks to Politics Today. With or Without Trump.” The New York Times. The New York Times, 12 June 2017, https:// www.nytimes.com/2017/06/12/theater/julius-caesar-shakespeare-donaldtrump.html. Accessed 22 June 2017.

Crystal, David. 'Think on My Words': Exploring Shakespeare's Language. Cambridge University Press, 2008.

Delgado, Richard, and Jean Stefancic. Critical Race Theory: An Introduction. New York University Press, 2001.

Emerson, Ralph Waldo. "Shakespeare; or, the Poet." Shakespeare in America: An Anthology from the Revolution to Now, edited by James Shapiro, the Library of America, 2014, pp. 105-122.

Foster, Thomas C. How to Read Literature Like a Professor: A Lively and Entertaining Guide to Reading Between the Lines. Revised ed., Harper Perennnial, 2014.

Foucault, Michel. "The Discourse on Language.” The Archeology of Knowledge and the 
Discourse on Language. Translated by Rupert Swyer, Vintage Books, 1972, pp. 215-237.

--. “What Is an Author?" Literary Theory: An Anthology. $3^{\text {rd }}$ ed., edited by Julie Rivkin, and Michael Ryan, Wiley Blackwell, 2017, 217-229.

Hay, John. “23 August 1863, Sunday.” Inside Lincoln's White House: The Complete Civil War Diary of John Hay, edited by Michael Burlingame, and John R. Turner Ettlinger, Southern Illinois University Press, 1997, 75-76.

Holmes, Oliver Wendell. "Shakespeare. Tercentennial Celebration.: April 23, 1864.” Shakespeare in America: An Anthology from the Revolution to Now, edited by James Shapiro, the Library of America, 2014, pp. 190-192.

Hutcheon, Linda. A Theory of Adaptation. $2^{\text {nd }}$ ed., Routledge, 2013.

Jonson, Ben. "To the Memory of My Beloved, the Author Mr. William Shakespeare: And What He Hath Left Us." The Norton Shakespeare. $3^{\text {rd }}$ ed., edited by Stephen Greenblatt, Walter Cohen, Suzanne Gossett, Jean E. Howard, Katharine Eisaman Maus, and Gordon McMullan, W. W. Norton \& Company, 2016, pp. A28-A30.

Klages, Mary. "Race and Postcolonialism." Literary Theory: The Complete Guide, Bloomsbury, 2017, pp. 117-139.

Levine, Lawrence W. "William Shakespeare in America." Highbrow/Lowbrow: The 
Emergence of Cultural Hierarchy in America, Harvard University Press, 1988, pp. 11-81.

Lincoln, Abraham. "Letter to James H. Hackett." Shakespeare in America: An Anthology from the Revolution to Now, edited by James Shapiro, the Library of America, 2014, pp. 181-182.

Lodge, Henry Cabot. "Shakespeare's Americanisms." Shakespeare in America: An Anthology from the Revolution to Now, edited by James Shapiro, the Library of America, 2014, pp. 254-265.

Loring, Frederick Wadsworth. "In the Old Churchyard at Fredericksburg." Shakespeare in America: An Anthology from the Revolution to Now, edited by James Shapiro, the Library of America, 2014, pp. 217-219

Marienstras, Richard. "Orson Welles: Shakespeare, Welles, and Moles." Orson Welles: Interviews, edited by Mark W. Estrin, University Press of Mississippi, 2002, pp. 146-172.

Marx, Steven. "Introduction: 'Kiss the Book."' Shakespeare and the Bible, Oxford University Press, 2000, pp. 1-18.

Maungwudaus. "Indians of North America." Shakespeare in America: An Anthology from the Revolution to Now, edited by James Shapiro, the Library of America, 2014, pp. 60-61. 
McGarrity, Michael C., and Calvin A. Shivers. "Confronting White Supremacy." Government Printing Office, 2019, https://www.fbi.gov/news/testimony/ confronting-white-supremacy.

Preston, Mary. Studies in Shakspeare: A Book of Essays. Philadelphia, 1869.

Rawlings, Peter, editor. Americans on Shakespeare: 1776-1914. Ashgate, 1999.

Sanders, Julie. Adaptation and Appropriation. $2^{\text {nd }}$ ed., Routledge, 2016.

Schmidt, Benjamin. "The Humanities Are in Crisis.” The Atlantic, 23 Aug. 2018, https://www.theatlantic.com/ideas/archive/2018/08/the-humanities-face-acrisisof-confidence/567565/. Accessed 31 Oct. 2019.

Sewall, Jonathan M. "Epilogue to Coriolanus." Shakespeare in America: An Anthology from the Revolution to Now, edited by James Shapiro, the Library of America, 2014, pp. 5-7.

Shaffer, Claire. “'Julius Caesar' Theater Defends Trump-Like Depiction After Delta Air Lines, Bank of America Pull Support.” Newsweek, 12 June 2017, https:// www.newsweek.com/public-theater-donald-trump-julius-caesar-response-624639. Accessed 6 Nov. 2019.

Shakespeare, William. Antony and Cleopatra. The Norton Shakespeare. $3^{\text {rd }}$ ed., edited by 
Stephen Greenblatt, Walter Cohen, Suzanne Gossett, Jean E. Howard, Katharine Eisaman Maus, and Gordon McMullan, W. W. Norton \& Company, 2016, pp. $2775-2864$.

--. Coriolanus. The Norton Shakespeare. $3^{\text {rd }}$ ed., edited by Stephen Greenblatt, Walter

Cohen, Suzanne Gossett, Jean E. Howard, Katharine Eisaman Maus, and Gordon McMullan, W. W. Norton \& Company, 2016, pp. 2933-3024.

--. Hamlet. The Norton Shakespeare. $3^{\text {rd }}$ ed., edited by Stephen Greenblatt, Walter Cohen, Suzanne Gossett, Jean E. Howard, Katharine Eisaman Maus, and Gordon McMullan, W. W. Norton \& Company, 2016, pp. 1751-1905.

--. Julius Caesar. The Norton Shakespeare. $3^{\text {rd }}$ ed., edited by Stephen Greenblatt, Walter Cohen, Suzanne Gossett, Jean E. Howard, Katharine Eisaman Maus, and Gordon McMullan, W. W. Norton \& Company, 2016, pp. 1685-1749.

--. Macbeth. The Norton Shakespeare. $3^{\text {rd }}$ ed., edited by Stephen Greenblatt, Walter Cohen, Suzanne Gossett, Jean E. Howard, Katharine Eisaman Maus, and Gordon McMullan, W. W. Norton \& Company, 2016, pp. 2709-2773.

--. Othello. The Norton Shakespeare. $3^{\text {rd }}$ ed., edited by Stephen Greenblatt, Walter Cohen, Suzanne Gossett, Jean E. Howard, Katharine Eisaman Maus, and Gordon McMullan, W. W. Norton \& Company, 2016, pp. 2073-2158.

--. Richard the Third. The Norton Shakespeare. $3^{\text {rd }}$ ed., edited by Stephen Greenblatt, 
Walter Cohen, Suzanne Gossett, Jean E. Howard, Katharine Eisaman Maus, and Gordon McMullan, W. W. Norton \& Company, pp. 555-647.

--. The First Part of Henry the Sixth. The Norton Shakespeare. $3^{\text {rd }}$ ed., edited by Stephen

Greenblatt, Walter Cohen, Suzanne Gossett, Jean E. Howard, Katharine Eisaman Maus, and Gordon McMullan, W. W. Norton \& Company, 2016, pp. 415-490.

--. The Tempest. The Norton Shakespeare. $3^{\text {rd }}$ ed., edited by Stephen Greenblatt, Walter Cohen, Suzanne Gossett, Jean E. Howard, Katharine Eisaman Maus, and Gordon McMullan, W. W. Norton \& Company, 2016, pp. 3205-3266.

--. Timon of Athens. The Norton Shakespeare. $3^{\text {rd }}$ ed., edited by Stephen Greenblatt, Walter Cohen, Suzanne Gossett, Jean E. Howard, Katharine Eisaman Maus, and Gordon McMullan, W. W. Norton \& Company, 2016, pp. 2571-2634.

Shapiro, James, editor. Shakespeare in America: An Anthology from the Revolution to Now. The Library of America, 2014.

"Sharp Partisan Divisions in Views of National Institutions." Pew Research Center for the People and the Press, 24 Sept. 2018, https://www.people-press.org/2017/07/ 10/sharp-partisan-divisions-in-views-of-national-institutions/.

Sillen, Samuel. "Paul Robeson's Othello." Shakespeare in America: An Anthology from the Revolution to Now, edited by James Shapiro, the Library of America, 2014, pp. 451-458. 
Sprague, Charles. "Prize Ode." Shakespeare in America: An Anthology from the Revolution to Now, edited by James Shapiro, the Library of America, 2014, pp. $36-37$.

Thomson, David. "Something Deathless and Dangerous." Rosebud: The Story of Orson Welles, Alfred A. Knopf, 1996, pp. 81-86.

Thoreau, Henry D. "Advantages and Disadvantages of Foreign Influence on American Literature." Americans on Shakespeare: 1776-1914, edited by Peter Rawlings, Ashgate, 1999, pp. 67-69.

Thorndike, Ashley. "Shakespeare in America." Americans on Shakespeare: 1776-1914, edited by Peter Rawlings, Ashgate, 1999, pp. 512-526.

Tocqueville, Alexis de. "The Literary Aspect of Democratic Centuries." Democracy in America, translated by Arthur Goldhammer, vol. 2, the Library of America, 2004, pp. 538-543.

United States, Federal Bureau of Investigation. "Offenders." Government Printing Office, 2017, https://ucr.fbi.gov/hate-crime/2017/topic-pages/offenders.pdf.

"Visit." Folger Shakespeare Library, 15 Feb. 2019, https://www.folger.edu/visit.

Wahlquist, Calla, and Lois Beckett. “'This Is Violence against Donald Trump': 
Rightwingers Interrupt Julius Caesar Play.” The Guardian, 17 June 2017. https:// www.theguardian.com/us-news/2017/jun/17/trump-supporter-interruptscontroversial-julius-caesar-play-in-new-york. Accessed 22 June 2017.

Westfall, Alfred Van Rensselaer. "Our Presidents as Shakespearean Critics." American Shakespearean Criticism: 1607-1865, Benjamin Blom, 1968, 220-230.

Whicher, George F. "Shakespeare for America." Shakespeare in America: An Anthology from the Revolution to Now, edited by James Shapiro, the Library of America, 2014, pp. 401-417.

Whipple, Sidney B. “Orson Welles's Julius Caesar.” Shakespeare in America: An Anthology from the Revolution to Now, edited by James Shapiro, the Library of America, 2014, pp. 441-458.

Zurcher, Anthony. “Trump Impeachment: Why Pelosi Made Her Move - and What Happens Next?" BBC News, 24 Sept. 2019, https://www.bbc.com/news/world-uscanada-49819351. Accessed 6 Nov. 2019. 